\title{
Host Range and Molecular Phylogenies of the Soft Rot Enterobacterial Genera Pectobacterium and Dickeya
}

\author{
Bing Ma, Michael E. Hibbing, Hye-Sook Kim, Ralph M. Reedy, Iris Yedidia, Jane Breuer, Jeffrey Breuer, \\ Jeremy D. Glasner, Nicole T. Perna, Arthur Kelman, and Amy O. Charkowski
}

First, eighth, and ninth authors: Genome Center of Wisconsin, University of Wisconsin-Madison, 425G Henry Mall, Madison 53706; second author: Department of Biology, Indiana University, 1001 East Third Street, Bloomington 47405-370; third, fourth, and eleventh authors: Department of Plant Pathology, 1630 Linden Dr., University of Wisconsin-Madison, Madison 53706; fourth author: Department of Ornamental Horticulture, Derech Hamakabim, ARO, Volcani Center, Bet Dagan 50250, Israel; fifth and sixth authors: Hancock Agricultural Research Station, N3909 County Rd V, Hancock, WI 54943; and tenth author: Department of Plant Pathology, North Carolina State University, 3419 Gardner Hall, Raleigh 27695-7616.

Accepted for publication 21 April 2007.

\begin{abstract}
Ma, B., Hibbing, M. E., Kim, H.-S., Reedy, R. M., Yedidia, I., Breuer, J., Breuer, J., Glasner, J. D., Perna, N. T., Kelman, A., and Charkowski, A. O. 2007. Host range and molecular phylogenies of the soft rot enterobacterial genera Pectobacterium and Dickeya. Phytopathology 97:11501163

Pectobacterium and Dickeya spp. are related broad-host-range enterobacterial pathogens of angiosperms. A review of the literature shows that these genera each cause disease in species from at least $35 \%$ of angiosperm plant orders. The known host ranges of these pathogens partially overlap and, together, these two genera are pathogens of species from $50 \%$ of angiosperm plant orders. Notably, there are no reported hosts for either genus in the eudicots clade and no reported Dickeya hosts in the

magnoliids or eurosids II clades, although Pectobacterium spp. are pathogens of at least one plant species in the magnoliids and at least one in each of the three eurosids II plant orders. In addition, Dickeya but not Pectobacterium spp. have been reported on a host in the rosids clade and, unlike Pectobacterium spp., have been reported on many Poales species. Natural disease among nonangiosperms has not been reported for either genus. Phylogenetic analyses of sequences concatenated from regions of seven housekeeping genes ( $a c n A, \operatorname{gap} A, i c d A, m d h, m t l D, p g i$, and $p r o A)$ from representatives of these genera demonstrated that Dickeya spp. and the related tree pathogens, the genus Brenneria, are more diverse than Pectobacterium spp. and that the Pectobacterium strains can be divided into at least five distinct clades, three of which contain strains from multiple host plants.
\end{abstract}

Pectobacterium spp. Waldee, 1945 (formerly Erwinia carotovora, Winslow et al. 1920) and Dickeya spp. Samson et al. 2005 (formerly Erwinia chrysanthemi, Burkholder et al. 1953) species are related soft rot enterobacterial pathogens with broad host ranges. These species formerly were known as the soft rot $\mathrm{Er}$ winia spp., but several studies have shown that the soft rot enterobacteria and E. amylovora, the type strain of the Erwinia genus, are too divergent to be included in one clade; therefore, the soft rot Erwinia spp. were moved to two new genera as Pectobacterium and Dickeya $(47,52,112,143)$.

Pectobacterium and Dickeya spp. are considered broad-hostrange pathogens in part because they have been isolated from so many plant species and in part because single strains are pathogens of numerous plant species under experimental conditions. In contrast, some plant pathogens, such as Clavibacter michiganensis, can cause disease on only a limited number of plant species. Other pathogens, such as Pseudomonas syringe, as a species can cause disease on a wide range of hosts, but individual $P$. syringae strains have narrow host ranges limited to a single plant species or even varieties within a single plant species.

Exceptions to the broad-host-range nature of Pectobacterium spp. are the species Pectobacterium atrospeticum Gardan et al. 2003, which is reported almost exclusively on potato (Solanum tuberosum L.), and P. betavasculorum Gardan et al. 2003, which is reported almost exclusively on sugar beet. Genetic analysis of

Corresponding author: A. O. Charkowski; E-mail address: amyc@plantpath.wisc.edu

doi:10.1094/PHYTO-97-9-1150

(C) 2007 The American Phytopathological Society
P. atrosepticum strains has shown that they are all closely related and suggests that there is limited diversity in $P$. atrosepticum compared with Pectobacterium spp. as a whole $(11,34)$. Similarly, there appears to be specialization for pathogenesis of maize (Zea mays L.) among some Dickeya strains $(73,99)$. However, the genetic basis for this apparent specialization is not yet known for either Pectobacterium or Dickeya spp.

There are no recent reviews cataloging the host range of these two genera and there has been little or no genetic characterization of soft rot enterobacterial strains from most host species. In the past, soft rot enterobacterial strains isolated from new hosts were identified, usually by biochemical reactions, as either E. carotovora subsp. carotovora or E. chrysanthemi, and little attempt was made to determine how strains from newly reported hosts were related to other strains of these bacterial species. Therefore, we do not know if, for example, Pectobacterium strains isolated from sunflower are all members of a particular genetic clade, just as all $P$. atrosepticum strains are closely related to each other. Unfortunately, obtaining cultures of the strains that have been reported is difficult or impossible; therefore, it is not possible to connect previous reports of soft rot enterobacterial pathogens to current enterobacterial taxonomy. Recently, there has been more effort to type strains isolated from various hosts. For example, PalacioBielsa et al. (102) found that four different Dickeya biovars could be isolated from potato in Spain, which allows some comparison among biovars found on potato and other hosts.

Recently, we examined the genetic diversity of Pectobacterium strains isolated from potato and found considerable diversity (146), similar to previous work using other methods, such as fatty acid analysis (34). This led us to hypothesize that multiple sub- 
types of Pectobacterium were pathogens of potato and also led us to question the relationship of Pectobacterium strains that cause disease in potato with Pectobacterium strains from other host plants.

To address this question, we obtained Pectobacterium and Dickeya strains isolated from a variety of plant species and employed multilocus phylogenetic analysis to characterize the relationship between these nominal species and subspecies. We chose to use a multilocus approach because it has been demonstrated to be more reliable than single-gene phylogenies. In addition, in at least one other system, this method was better correlated with DNA:DNA hybridization assays than phylogenies built from $16 \mathrm{~S}$ rRNA genes (100). We also chose this method because it is inexpensive, relatively simple, and allows researchers to easily share phylogenetic data without the necessity of sharing strain collections. Unfortunately, obtaining numerous cultures from type collections is often cost prohibitive for laboratories and it is difficult to obtain permits for some bacterial pathogens. Therefore, our goal was also to determine whether multilocus phylogenetic analysis provided enough information to group strains into clades with high statistical support. This robust phylogeny served as a foundation to compare the genetic relationships of the strains with the phylogenetic distribution of hosts to complement our extensive compilation from the literature.

\section{MATERIALS AND METHODS}

Isolation of Pectobacterium spp. Plant samples were obtained from commercial growers, including marigold (Tagetes erecta L.), cabbage (Brassica oleracea var. capitata L.), pepper (Capsicum spp.), potato, and Ornithogalum spp., and during examination of wild plants growing on the edges of farms (Arctium minus Bernh.). Pectobacterium strains were isolated from plant samples using standard protocols (33) or on raffinose medium (RAF) without antibiotics (115) (Table 1). The plates were incubated at room temperature for up to 3 days and colonies that had formed pits in the CVP or that were red on the RAF medium were restreaked onto Luria-Bertani (LB) medium. If colonies with different morphologies were present on LB, bacteria were streaked from individual colonies to obtain pure cultures. Cultures then were streaked on CVP to determine whether all of the resulting colonies were pectolytic. Cultures obtained from single colonies were stored in $20 \%$ glycerol at $-80^{\circ} \mathrm{C}$. All strains except those from A. minus were tested for pathogenicity on the host species that they were isolated from and most also were tested for ability to macerate potato tubers. Although we collected several seed from A. minus, we were unable to get the seed to germinate and, thus, were unable to test the A. minus strain WPP236 for pathogenicity on A. minus. WPP236 was able to macerate potato tubers.

Strains that varied in host or biological phenotypes, such as the presence of a type III secretion system, carbon source utilization, or relative virulence, were included in our analysis. We focused on strains for which there was a wealth of biological information. For example, there are genome sequences available for $P$. atrosepticum SCRI 1043 and Dickeya dadantii 3937 (12) (J. D. Glasner, unpublished data), a partial genome sequence is available for $P$. carotovorum WPP14, and numerous mutant analyses have been completed with Ecc $71(23,24,29,83)$. Among the 52 strains that were used in our analysis, 39 have been reported on in other studies (Table 1) and the majority are available in other culture collections.

Literature review. Because, in most cases, it is not possible to determine which species or subspecies of Pectobacterium or Dickeya were isolated from the various plant species based on the information provided in the initial reports, we summarized the host range of these two genera rather than trying to determine the host range of particular soft rot enterobacterial species. Our goal was to include in our analysis only reports that met the following criteria: (i) the isolated pathogen was clearly demonstrated to be a member of the soft rot enterobacteria by DNA analyses or phenotypic tests; (ii) Koch's postulates were completed, demonstrating that the isolated Erwinia strain indeed could cause disease on the host plant; and (iii) the report described naturally occurring diseases and not laboratory host range studies. One exception was the inclusion of Amusa and Baiyewu (5), which describes Pectobacterium soft rot of yam (Dioscorea L. spp.). Unfortunately, we were unable to obtain a copy of this report, but decided to include it in our analysis because it has been referenced by other authors.

DNA isolation, polymerase chain reaction amplification, and DNA sequencing. Bacterial cultures were revived from frozen stocks, streaked onto LB agar, and then inoculated into LB broth. The cultures were grown in a shaking incubator at $25^{\circ} \mathrm{C}$ for P. atrosepticum and E. amylovora Winslow et al. 1920 and $36^{\circ} \mathrm{C}$ for all other strains. DNA was extracted from overnight broth cultures as described by Staskawicz et al. (124). The precipitated DNA then was quantified using a SPECTRAmax Plus (Molecular Devices Corporation, Sunnyvale, CA), adjusted to $50 \mathrm{ng} / \mu \mathrm{l}$ and stored at $4^{\circ} \mathrm{C}$.

The acnA, gapA, icdA, $m d h, m t l D, p g i$, and proA genes were chosen for multilocus sequence analysis because they are present in most enterobacteria, their products are involved in diverse aspects of bacterial metabolism, preliminary analysis suggested that there would be enough sequence diversity in these genes to allow us to reconstruct bacterial phylogenies, and these genes are not clustered in the genome. Gene homoplasy was tested using methods described by Farris (44) using PAUP* 4.0 b10 (127). Portions of seven genes were amplified by polymerase chain reaction (PCR) from 53 strains (Table 1). The gene fragments were amplified and sequenced with primers designed to anneal to conserved motifs (Table 2). A 25- $\mu$ PCR mix contained the following: $9.5 \mu \mathrm{l}$ of water; $12.5 \mu \mathrm{l}$ of Master Mix (50 units/ml Taq DNA polymerase, $400 \mathrm{mM}$ dNTP dilution mix, $3 \mathrm{mM} \mathrm{MgCl}_{2}$, and buffer solution) (Promega Corp., Madison, WI); $0.8 \mathrm{mM}$ forward and reverse primer solutions; and $1 \mu \mathrm{l}$ of diluted DNA template. PCR amplifications were carried out in a TGradient 96 well thermocycler (Biometra, Goettinggen, Germany) with the following steps: (i) a hot start at $95^{\circ} \mathrm{C}$ for $3 \mathrm{~min}$; (ii) 30 amplification cycles of $94^{\circ} \mathrm{C}$ for $0.5 \mathrm{~min}, 52^{\circ} \mathrm{C}$ for $0.5 \mathrm{~min}$, and $72^{\circ} \mathrm{C}$ for $1 \mathrm{~min}$; and (iii) a terminal extension phase at $72^{\circ} \mathrm{C}$ for $6 \mathrm{~min}$.

The PCR products were purified via precipitation using the QIAquick PCR purification kit (Qiagen, Valencia, CA), the Wizard SV Gel and PCR Cleanup System (Promega Corp.), or AMPure magnetic beads (Agencourt Bioscience Co., Beverly, MA). The DNA was resuspended in $25 \mu \mathrm{l}$ of $\mathrm{dH}_{2} \mathrm{O}$ and quantified by spectrophotometry, and the DNA template for sequencing was prepared at a concentration of $2 \mathrm{ng} / \mu \mathrm{l}$ per $100 \mathrm{bp}$ of PCR product length. Low-yield PCR products from problematic taxa were reamplified from Tris-acetate-EDTA gel-purified bands (QIAquick gel extraction kit; Qiagen) prior to sequencing.

Sequencing reactions were performed with $2 \mu \mathrm{l}$ of ABI BigDye Terminator Cycle Sequencing Ready Reaction Mix (Applied Biosystems, Foster City, CA) following the manufacturer's protocol. CleanSeq magnetic beads (Agencourt Bioscience Co.) were used to purify the sequencing reactions following the manufacturer's instructions. Automated sequencing was conducted on an ABI3730 automated sequencer in the DNA sequence laboratory at the University of Wisconsin Biotech Center. Sequence chromatogram output files initially were aligned and edited using SeqManII (DNASTAR Inc., Madison, WI). The sequences were deposited in GenBank under accession numbers EF550599 to EF550964.

Phylogenetic analyses. Phylogenetic analyses of 53 taxa (Table 1) were conducted in PAUP* $4.0 \mathrm{~b} 10$ using a concatenated data set of partial acnA, gapA, icdA, mdh, mtID, pgi, and proA DNA sequences with Yersinia pestis van Loghem 1944 and Y. pseudotuberculosis Smith and Thal 1965 used as outgroup 
species. The Yersinia sequences were obtained from GenBank (GenBank accession numbers AE017042, AL590842, AE009952, and NC_006155). The alignment for this data set was performed in MegAlign 5.08 (DNASTAR) in slow-accurate mode with a pairwise alignment gap opening penalty of 10 and a gap extension penalty of 0.1 , and multiple alignment gap extension penalty of 0.2 . The most suitable model of sequence evolution for each partition was determined using Modeltest 3.6 (November 2004 edition) $(105,106)$, and corresponding parameter values were estimated in PAUP* 4.0b10. Based on this model, the corresponding likelihood parameters were estimated and then applied in PAUP* 4.0b10. Several phylogenies were produced using different methods, including uncorrected and maximum likelihood corrected neighbor joining, unweighted parsimony, and parsimony with substitutions weighted according to the instantaneous rate matrix or characters weighted according to their rescaled consistency (RC) values. Resultant phylogenies were used as starting trees for maximum likelihood estimation under the estimated likelihood parameters. Bootstrap analysis was performed using 5,000 replicates with sampling limited to parsimony-informative characters.

TABLE 1. Strains used in this study

\begin{tabular}{|c|c|c|c|}
\hline Strain $^{\mathrm{a}}$ & Origin & Source $^{b}$ & Other studies ${ }^{\mathrm{c}}$ \\
\hline \multicolumn{4}{|l|}{ Brenneria spp. } \\
\hline EniD312 & Juglans regia $\mathrm{L}$. & S. V. Beer & $\ldots$ \\
\hline Equ11D3 & Quercus spp. L. & S. V. Beer & $\ldots$ \\
\hline EluW3L16 & Lupinus spp. L. & S. V. Beer & 18 \\
\hline ATCC15712 & Salix alba $\mathrm{L}$. & S. V. Beer & 18 \\
\hline \multicolumn{4}{|l|}{ Dickeya spp. } \\
\hline 3937 (CFBP 3855) & Saintpaulia ionantha $\mathrm{H}$. Wendl., France & 79 & 112 \\
\hline 646 & Oryza sativa L., Japan & R. S. Dickey & $\ldots$ \\
\hline 721 & Aloe barbadensis L., Arizona & R. S. Dickey & $\ldots$ \\
\hline 600 & Ipomoea batatas L., Geogia & R. S. Dickey & $\ldots$ \\
\hline 586 & Philodendron Schott, Florida & R. S. Dickey & $\ldots$ \\
\hline 678 & Harrisia spp. Britton, California & R. S. Dickey & $\ldots$ \\
\hline 703 & Solanum tuberosum L., Australia & R. S. Dickey & $\ldots$ \\
\hline 0862 & Zea mays L. & A. Kelman & $\ldots$ \\
\hline 1591 & Z. mays & A. Kelman & $\ldots$ \\
\hline \multicolumn{4}{|l|}{ Pectobacterium spp. } \\
\hline \multicolumn{4}{|l|}{ P. atrosepticum } \\
\hline SCRI1043 (BAA-672) & S. tuberosum, Scotland & 12 & $\ldots$ \\
\hline Eca6 & S. tuberosum, British Columbia & 34 & 34,39 \\
\hline Eca31 & S. tuberosum, Wisconsin & 34 & $34,39,42$ \\
\hline \multicolumn{4}{|l|}{ P. betavasculorum } \\
\hline Ecb1 & Beta vulgaris L., California & R. Lewellen & $\ldots$ \\
\hline $\operatorname{Ecb} 2$ & B. vulgaris, California & R. Lewellen & $\ldots$ \\
\hline Ecb6 & B. vulgaris, California & R. Lewellen & $\ldots$ \\
\hline \multicolumn{4}{|l|}{ P. brasiliensis } \\
\hline BAA-417 (1692) (Ecbr212) & S. tuberosum, Brazil & V. Duarte & $39,42,112$ \\
\hline BAA-419 (1695) (Ecbr371) & S. tuberosum, Brazil & V. Duarte & 39,42 \\
\hline Psp938 & S. tuberosum, Brazil & V. A. Malavolta, Jr. & $\ldots$ \\
\hline Psp939 & S. tuberosum, Brazil & V. A. Malavolta, Jr. & $\ldots$ \\
\hline Psp940 & S. tuberosum, Brazil & L. O. S. Beriam & $\ldots$ \\
\hline WPP1 & S. tuberosum, Wisconsin, 2001 & 146 & 146 \\
\hline WPP17 & S. tuberosum, Wisconsin, 2001 & 146 & 146 \\
\hline WPP165 & S. tuberosum, Wisconsin, 2004 & This study & $\ldots$ \\
\hline Ec87 & S. tuberosum, Israel & This study & $\ldots$ \\
\hline Ec105 & Onithogalum spp. L. stem, Israel & This study & $\ldots$ \\
\hline Ec46 & Capsicum апиит L., Israel & This study & $\ldots$ \\
\hline \multicolumn{4}{|l|}{ P. carotovorum } \\
\hline Ecc21 & S. tuberosum, Netherlands & 34 & 34,39 \\
\hline Ecc63 & S. tuberosum, Netherlands & 34 & 34,39 \\
\hline Ecc71 & S. tuberosum, Netherlands & 34 & 34,39 \\
\hline Ecc190 & S. tuberosum, New York & 34 & 34 \\
\hline Ecc193 & S. tuberosum, British Columbia & 34 & 34,39 \\
\hline $\operatorname{Ecc} 380$ & S. tuberosum, Oregon & 34 & 34 \\
\hline WPP14 & S. tuberosum, Wisconsin, 2001 & 146 & 146 \\
\hline WPP220 & Tagetes patula L., Wisconsin, 2005 & This study & $\ldots$ \\
\hline WPP221 & Tagetes patula, Wisconsin, 2005 & This study & $\ldots$ \\
\hline WPP236 & Arctium minus Bernh., Wisconsin, 2005 & This study & $\ldots$ \\
\hline SCRI 482 (NCPPB 3840) (CFBP 1879) & Cichorium intybus L., France & 46 & 11 \\
\hline Ec97 & Brassica oleracea L., Israel & This study & $\ldots$ \\
\hline \multicolumn{4}{|l|}{ P. wasabiae } \\
\hline SCRI 488 & Eutrema wasabi Maxim. & Y. Bertheau & 11 \\
\hline WPP19 & S. tuberosum, Wisconsin, 2001 & 146 & 146 \\
\hline WPP161 & S. tuberosum, Wisconsin, 2004 & This study & $\ldots$ \\
\hline WPP163 & S. tuberosum, Wisconsin, 2004 & This study & $\ldots$ \\
\hline WPP168 & S. tuberosum, Wisconsin, 2004 & This study & $\ldots$ \\
\hline WPP172 & S. tuberosum, Wisconsin, 2004 & This study & $\ldots$ \\
\hline \multicolumn{4}{|l|}{ Pectobacterium spp. } \\
\hline Ec106 & Ornithogalum spp. bulb, Israel & This study & $\ldots$ \\
\hline
\end{tabular}

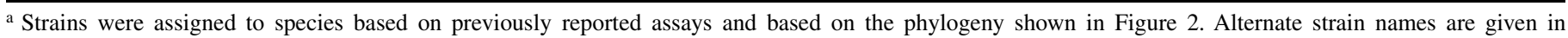
parenthesis.

b Cultures from R. S. Dickey's collection were provided by A. Collmer.

c References for other phylogenetic or diversity studies using these strains. 
MrBayes v. 3.0b4 (59-61) also was used with the same set of data and outgroups. Each run was composed of four chains starting from random trees, and 5,000,000 generations with trees sampled every 100 generations. The majority rule consensus tree was calculated after the removal of first 500 trees corresponding to a burn-in period (burn-in period is estimated based on log likelihood curve; data not shown).

Topologies resulting from each of the above phylogenetic analyses were compared through a one-tailed Shimodaira and Hasegawa (SH) test $(118,119)$ implemented by PAUP* $4.0 \mathrm{~b} 10$. Test distributions were generated using 10,000 resampling estimated log-likelihood (RELL) bootstrap replicates (48).

\section{RESULTS AND DISCUSSION}

The host range of the soft rot enterobacteria. There are reports of Pectobacterium or Dickeya hosts in one-half of angiosperm plant orders, and these host ranges overlap but are not identical. In the 1990s, A. Kelman began compiling a comprehensive list of all soft rot enterobacterial host species. The initial goal was to provide a listing of the first reliable peer-reviewed reports of Pectobacterium and Dickeya spp. causing disease on particular host species, to determine the extent that the reported host ranges of these two species overlap, and to determine the actual breadth of the host range of these bacterial plant pathogens. The identification of plant orders that lack reported hosts of soft rot enterobacteria are informative in that they describe plant groups where either no one has searched for soft rot disease or, possibly, plant families or orders have attributes that provide resistance to soft rot enterobacteria, such as high cell wall calcium content or low intercellular $\mathrm{pH}$.

The taxonomy of the soft rot enterobacteria has been complicated, with many species names proposed and discarded, and it is not always clear from the reports whether Pectobacterium, Dickeya, or perhaps another soft rot enterobacterial genus is being described. Therefore, we included reports only where the genus appears to be either Pectobacterium or Dickeya and not reports that identified the bacteria only as a soft rot enterobacterial species. Like many plant pathogens, soft rot enterobacteria also have been reported on healthy plants from numerous species $(90,93)$. These asymptomatic hosts are not included in this review.

In cases where the biochemical tests do not clearly match with either Pectobacterium or Dickeya, we used the identification provided by the authors unless subsequent reports on the same strains resulted in a new identification. One notable case of this is the stalk rot pathogen of maize, which was identified initially as a subspecies of E. carotovora (Pectobacterium) (111) at approximately the same time that the genus Dickeya was first described by Burkholder (19). Based on the descriptions of the bacterial strains and the later publications by some of the same authors who initially reported this maize pathogen as E. carotovora, it appears that this pathogen is consistently a Dickeya sp. and that there are no reliable reports of Pectobacterium causing disease on maize or any other Poales species.

One other case merits special mention. In 1942, a Pectobacterium sp. was reported on saguaro cacti (Carnegiea gigantea Britton and Rose 1908) (80), but the type culture was lost and the name has been rejected (2). Cactus pathogens later were isolated by Alcorn et al. (3) and a recent phylogenetic analysis of $16 \mathrm{~S}$ rRNA sequences suggests that the cactus pathogen is more closely related to Pectobacterium than Dickeya spp. Eventually, P. cacticida Alcorn et al. 1991 may be moved to another genus; however, for this analysis, we have included it with the genus Pectobacterium.

In our literature review, we found that Pectobacterium spp. were reported as pathogens of species in 16 dicot plant families in 11 orders, and species in 11 monocot families in 6 orders (Tables 3 and 4; Fig. 1). Dickeya spp. were reported to cause disease in plant species in 11 dicot families in 10 plant orders, and species in 10 monocot families in 5 orders. In many cases, only one report of one species per family and order could be found. It is likely that additional species in these families and orders are soft rot enterobacterial hosts.

Although Pectobacterium and Dickeya spp. cause disease in many identical host species, their reported host ranges do not completely overlap. Of the 21 dicot and 16 monocot plant families reported as hosts for either Pectobacterium or Dickeya spp., only 6 dicot and 4 monocot families have been reported as hosts for both genera. This lack of host overlap extends in part to higher levels of classification (Fig. 1). For example, Pectobacterium has been reported on avocado (Persea americana Miller) (140), which is in the magnoliids clade (15), but there are no reports of Dickeya spp. causing disease in any magnoliids clade species. We could find no reports of soft rot enterobacteria causing disease under natural conditions in nonangiosperms, the basal angiosperm orders, or the eudicots clade. Because there are so few reports for some plant clades, such as the magnoliids, the partial lack of overlap in the Pectobacterium and Dickeya host ranges may be due to a paucity of reports for plant hosts in these clades.

TABLE 2. Primers used in this study

\begin{tabular}{|c|c|c|c|c|c|c|}
\hline Gene & Full name & Sequence length ${ }^{\mathrm{a}}$ & Primer name & Primer sequence & $\mathrm{Tm}$ & Bases \\
\hline \multirow[t]{2}{*}{$\operatorname{acn} A$} & Aconitate hydrase 1 & 300 & $\operatorname{acn} A 3 F$ & CMA GRG TRT TRA TGC ARG AYT TTA C & 54.2 & 25 \\
\hline & & & acnA3R & GAT CAT GGT GGT RTG SGA RTC VGT & 60.2 & 24 \\
\hline gapA & Glyceraldehyde-3-phosphate dehydrogenase A & 450 & gapA326F & ATC TTC CTG ACC GAC GAA ACT GC & 60.7 & 23 \\
\hline \multirow[t]{2}{*}{$i c d A$} & Isocitrate dehydrogenase, specific for NADP+ & 520 & icdA400F & GGT GGT ATC CGT TCT CTG AAC G & 58.4 & 22 \\
\hline & & & icdA977R & TAG TCG CCG TTC AGG TTC ATA CA & 59.5 & 23 \\
\hline \multirow[t]{2}{*}{$m d h$} & Malate dehydrogenase & 460 & mdh86F & CCC AGC TTC CTT CAG GTT CAG A & 60.1 & 22 \\
\hline & & & mdh628R & CTG CAT TCT GAA TAC GTT TGG TCA & 57.3 & 24 \\
\hline \multirow{2}{*}{$m t l D$} & $\ldots$ & $\ldots$ & mtIDF & CTG YTG GAT GCI CTS AAC MGY CG & 63.7 & 23 \\
\hline & $\ldots$ & & mltDR & TCC ACR GCR GAA TCW ACR AAT CC & 58.3 & 23 \\
\hline \multirow[t]{5}{*}{$p g i$} & Glucose-6-phosphate isomerase & 520 & pgi815F & TGG GTC GGC GGC CGT TAC TC & 65.3 & 20 \\
\hline & $\ldots$ & $\ldots$ & pgi1396R & TGC CTT CGA ATA CTT TGA ACG GC & 59.5 & 23 \\
\hline & $\ldots$ & $\ldots$ & pgiF2 & CTG TCY ACC AAT GCS AAA GCC G & 59.9 & 22 \\
\hline & $\ldots$ & $\ldots$ & pgiR2 & CAG CAG GAT GGA GTT GGT CGG & 60.2 & 21 \\
\hline & $\ldots$ & $\ldots$ & pgiF & TCT YTI GGI TTT GAK AAY TTT GA & 53.0 & 23 \\
\hline
\end{tabular}

a Only the middle portion of sequence from each amplicon was used because the ends of the sequences included the degenerate primer sequences. 
However, there is some apparent specialization that is particularly striking. For example, there are Pectobacterium, but not Dickeya, hosts in all three of the plant orders in the eurosids II clade (Fig. 1), including cabbage (Brassicales), cotton (Gossypium hirsutum, Malvales), and mango (Mangifera indica L., Sapindales). Because these crop species are widely grown and studied, the lack of reports of Dickeya spp. soft rot hosts in the eurosids II clade may be significant. It is also notable that Dickeya spp., but not Pectobacterium spp., have been reported on several agriculturally important Poales spp., ranging from rice to maize. Because Poales spp. are so widely grown and studied, the lack of reports of Pectobacterium spp. on these hosts may be significant. Because PCR assays are now available that can distinguish between Dickeya and Pectobacterium spp. $(31,68,98)$, it should be a straightforward matter to survey diseased plants and determine whether Dickeya spp. can cause disease on eurosids II species, whether Pectobacterium spp. can cause disease in Poales spp., and whether either genus can cause disease in hosts from any of the many orders of plants that have never been reported to be hosts for soft rot enterobacteria.

Phylogenetic reconstructions indicate monophyly of Pectobacterium, Dickeya, and Brenneria lineages. To date, only phylogenies built with single genes have been used to examine the relationships of the plant-pathogenic enterobacteria $(18,47$, 52,112 ) and, because these single genes do not have many informative characters, they "may not accurately reflect interspecies taxonomic relatedness" (18). In these phylogenies, the bootstrap values for branches that describe how these three genera are related generally are either not significant or were not presented.

We chose fragments of seven housekeeping genes to examine the relatedness of these three genera. Several tests were used to

TABLE 3. Host species of the genera Pectobacterium and Dickeya

\begin{tabular}{|c|c|c|c|}
\hline \multirow[b]{2}{*}{ Host family } & \multirow[b]{2}{*}{ Host species } & \multicolumn{2}{|c|}{ References } \\
\hline & & Pectobacterium & Dickeya \\
\hline \multicolumn{4}{|l|}{ Dicotyledons } \\
\hline \multirow[t]{2}{*}{ Amaranthaceae (amaranth family) } & Beta vulgaris L. & $129,133,134^{\mathrm{a}}$ & No report \\
\hline & Spinacia oleracea $\mathrm{L}$. & 120 & No report \\
\hline Anacardiaceae (sumac family) & Mangifera indica Thwaites & 51 & No report \\
\hline \multirow[t]{4}{*}{ Apiaceae (carrot family) } & Apium graveolens Cham. & 145 & No report \\
\hline & Arracacia xanthorrhiza Bancr. & 108 & 53 \\
\hline & Coriandrum sativum $\mathrm{L}$. & 21 & No report \\
\hline & Daucus carota $\mathrm{L}$. & 66,67 & 137 \\
\hline \multirow[t]{9}{*}{ Asteraceae (daisy family) } & Arctium minus Bernh. & This work & No report \\
\hline & Chrysanthemum maximum (DC.) Parsa. & No report & 88 \\
\hline & Chrysanthemum $\times$ morifolium & No report & $19^{b}$ \\
\hline & Cichorium intybus $\mathrm{L}$. & 46 & 77 \\
\hline & Dahlia sp. Cav. & No report & 110 \\
\hline & Helianthus annuus L. & 9 & No report \\
\hline & Lactuca sativa $\mathrm{L}$. & 125,144 & No report \\
\hline & Parthenium argentatum A. Gray & 123 & No report \\
\hline & Tagetes patula $\mathrm{L}$. & 114 & No report \\
\hline Begoniaceae (begonia family) & Begonia bertinii & No report & 109 \\
\hline \multirow[t]{4}{*}{ Brassicaceae (mustard family) } & Eutrema wasabi Maxim. & 50 & No report \\
\hline & Brassica oleracea $\mathrm{L}$. & 10 & No report \\
\hline & Brassica rapa $\mathrm{L}$. & 139 & No report \\
\hline & Raphanus sativus L. & 141 & No report \\
\hline \multirow[t]{10}{*}{ Cactaceae (cactus family) } & Acanthocereus tetragonus Hummelinck & 3 & No report \\
\hline & Carnegiea gigantean Britton \& Rose & 3 & No report \\
\hline & Ferocactus wislizenii Britton \& Rose & 3 & No report \\
\hline & Opuntia ficus-indica Mill. & 3 & No report \\
\hline & Opuntia fulgida Engelm. & 3 & No report \\
\hline & Opuntia phaeacantha Engelm. & 3 & No report \\
\hline & Opuntia stricta Haw. & 3 & No report \\
\hline & Opuntia violacea Engelm. & 3 & No report \\
\hline & Stenocereus gummosus A. C. Gibson \& K. E. Horak & 3 & No report \\
\hline & Stenocereus thurberi Buxb. & 3 & No report \\
\hline Caryophyllaceae (pink family) & Dianthus caryophyllus L. & No report & 78 \\
\hline Convolvulaceae (morning glory family) & Ipomoea batatas Lam. & No report & 113 \\
\hline \multirow[t]{2}{*}{ Crassulaceae (stone crop family) } & Kalanchoë blossfeldiana Poelln. & 43 & 37 \\
\hline & & & (continued on next page) \\
\hline
\end{tabular}

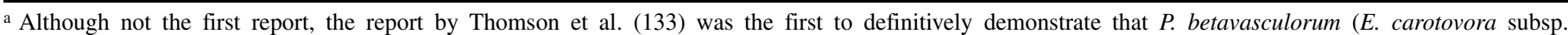
betavasculorum) differed from other Pectobacterium strains.

b This is the first time the name E. chrysanthemi was used.

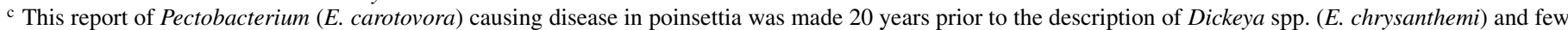
details are given. Therefore, it is possible that the pathogen described here is actually a Dickeya sp.

d Only alfalfa sprouts and nonmature plants have been reported as a host.

e Two references are included because Spurr (122) found both Pectobacterium and Dickeya spp. on tobacco.

f Two types of strains were recovered. One of them appears similar to Dickeya spp. by biochemical tests, but did not grow at $37^{\circ} \mathrm{C}$.

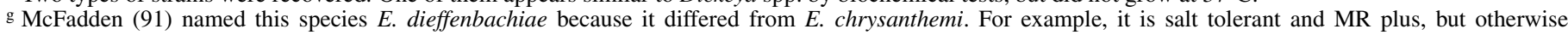
resembles E. chrysanthemi and is likely to be a Dickeya sp.

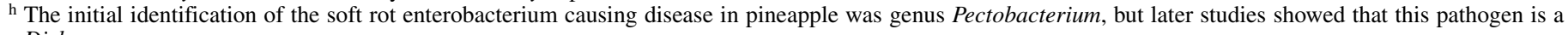
Dickeya sp.

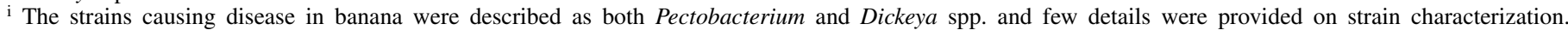
Therefore, it is unclear based on these reports whether species cause disease in banana. Dickey showed in later studies that strains from banana are Dickeya spp.

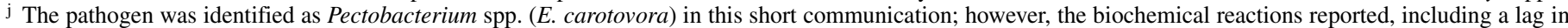
acid production from lactose, growth at $40^{\circ} \mathrm{C}$, indole production, MR negative, and VP positive indicate that the strain was more similar to a Dickeya sp.

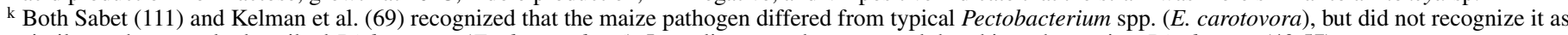
similar to the recently described Dickeya spp. (E. chrysanthemi). Later literature demonstrated that this pathogen is a Dicekya sp. (40,57). 
determine whether the gene fragments were equally informative and to examine the phylogenies constructed by different algorithms. To characterize these seven gene data sets, three indicators were used, including $\mathrm{f}$ values and $\mathrm{f}$ ratio, $\mathrm{RC}$ index, and homoplasy index (HI) (Table 5). The various goodness-of-fit statistics suggest that the rate of evolutionary divergence of the genes used in this study is sufficiently homogenous and they are appropriate and informative to perform a reasonable phylogenetic estimation. The branching orders of Pectobacterium, Dickeya, and other major lineages are recovered in phylogenies implemented in PAUP and the Bayesian reconstructions using the TrN method (130) with a $\gamma$ correction for rate variation and invariant sites, which was selected by Modeltest 3.6 as the most suitable model of sequence evolution based on hierarchical likelihood ratio tests (hLRTs). The selected model was applied using different computational algorithms implemented in PAUP* 4.0b10. A topology test (SH test) was performed on the phylogenies obtained from the uncorrected and maximum-likelihood-corrected neighbor joining, unweighted parsimony, and parsimony with substitutions weighted according to the instantaneous rate matrix or characters weighted according to their RC values (44), together with the last 50 trees produced by the Bayesian analysis. The maximum likelihood phylogeny based on the combined data set was selected to be the best tree among all the other phylogenies recovered from the different computational algorithms. The substitution and character weighted parsimony is the second-best tree, the last 50 trees produced in Bayesian are the third-best tree, and unweighted parsimony are not significantly worse than the maximum likelihood tree. However, trees based on both distance methods are significantly worse $(P<0.05)$.

The relationships of Pectobacterium, Dickeya, and Brenneria lineages and their relatives were recovered with high resolution

TABLE 3. (continued from preceding page)

\begin{tabular}{|c|c|c|c|}
\hline \multirow[b]{2}{*}{ Host family } & \multirow[b]{2}{*}{ Host species } & \multicolumn{2}{|c|}{ References } \\
\hline & & Pectobacterium & Dickeya \\
\hline \multirow[t]{3}{*}{ Cucurbitaceae (cucumber family) } & Cucurbita maxima Duchesne & 114 & No report \\
\hline & Cucurbita pepo L. & 121 & No report \\
\hline & Cucumis sativus $\mathrm{L}$. & 114 & No report \\
\hline \multirow[t]{2}{*}{ Euphorbiaceae (spurge family) } & Euphorbia pulcherrima Willd. ex Klotzsch & $25^{\mathrm{c}}$ & 55 \\
\hline & Manihot esculenta $\mathrm{Crantz}$ & 30 & No report \\
\hline Fabaceae (pea family) & Medicago sativa $\mathrm{L}$. & No report & $104^{\mathrm{d}}$ \\
\hline Geraniaceae (geranium family) & Pelargonium capitatum $\mathrm{L}$. & No report & 107 \\
\hline Gesneriaceae (African violet family) & Saintpaulia ionantha Wendl. & No report & 79 \\
\hline Lauraceae (laurel family) & Persea americana Mill. & 140) & No report \\
\hline Malvaceae (mallow family) & Gossypium hirsutum L. & 27,62 & No report \\
\hline Moraceae (mulberry family) & Morus spp. L. & 128 & No report \\
\hline Myrsinaceae (myrsine family) & Cyclamen spp. L. & 103 & 103 \\
\hline Primulaceae (primrose family) & Primula spp. L. & 89 & No report \\
\hline Rosaceae (rose family) & Pyrus communis L. & 21 & No report \\
\hline \multirow[t]{5}{*}{ Solanaceae (nightshade family) } & Capsicum annuum $\mathrm{L}$. & 142 & No report \\
\hline & Solanum lycopersicum L. & 87 & 4 \\
\hline & Nicotiana tabacum $\mathrm{L}$. & $56,122^{\mathrm{e}}$ & 122 \\
\hline & Solanum melongena $\mathrm{L}$. & No report & 70 \\
\hline & Solanum tuberosum L. & 6 & $131^{\mathrm{f}}$ \\
\hline \multicolumn{4}{|l|}{ Monocotyledons } \\
\hline Agavaceae (agave family) & Agave tequilana F. A. C. Weber & 64 & No report \\
\hline Alliaceae (onion family) & Allium cepa $\mathrm{L}$ & 116 & No report \\
\hline \multirow[t]{10}{*}{ Araceae (arum family) } & Aglaonema pictum Kunth & No report & 92 \\
\hline & Aechmea fasciata Baker & No report & 28 \\
\hline & Dieffenbachia spp. Schott & 26 & $91,97 \mathrm{~g}$ \\
\hline & Philodendron selloum K. Koch & No report & 94 \\
\hline & Scindapsus aureus Engl. & 71 & No report \\
\hline & Syngonium podophyllum Schott & No report & $72,75^{1}$ \\
\hline & Xanthosoma sagittifolia Schott & No report & 20 \\
\hline & Zantedeschia aethiopica Spreng & 138 & 76 \\
\hline & Zantedeschia elliottiana Burtt Davy & 8 & No report \\
\hline & Zantedeschia rehmannii Engl. & 7 & No report \\
\hline Arecaceae (palm family) & Phoenix dactylifera $\mathrm{L}$. & No report & 1 \\
\hline \multirow[t]{2}{*}{ Asphodelaceae (aloe family) } & Aloe arborescens Mill. & 10 & No report \\
\hline & Aloe vera Burm. F. & No report & 35,65 \\
\hline Bromeliaceae (bromeliad family) & Ananas comosus Merr. & No report & $81,132^{\mathrm{h}}$ \\
\hline Dioscoreaceae (yam family) & Dioscorea L. spp. & 5 & No report \\
\hline Hyacinthaceae (hyacinth family) & Ornithogalum spp. L. & No report & This work \\
\hline Iridaceae (iris family) & Iris $\times$ germanica & 58,74 & 74 \\
\hline Lilaceae (lily family) & Tulipa spp. L. & 14 & No report \\
\hline Musaceae (banana family) & Musa paradisiaca $\mathrm{L}$. & No report & $36,117,126^{\mathrm{i}}$ \\
\hline \multirow[t]{3}{*}{ Orchidaceae (orchid family) } & Cattleya spp. Lindl. & 82 & No report \\
\hline & Cymbidium spp. Sw. & 86 & No report \\
\hline & Phalaenopsis spp. Blume & 86 & 65 \\
\hline Pandanaceae (screw pine family) & Pandanus conoideus Lam. & 135 & No report \\
\hline \multirow[t]{5}{*}{ Poaceae (grass family) } & Brachiaria spp. Griseb & No report & 13 \\
\hline & Oryza sativa $\mathrm{L}$. & No report & 49 \\
\hline & Saccharum officinarum $\mathrm{L}$. & No report & $38^{\mathrm{j}}$ \\
\hline & Sorghum bicolor Moench & No report & 63 \\
\hline & Zea mays L. & No report & $57,69,111^{\mathrm{k}}$ \\
\hline Ruscaceae (lily of the valley family) & Dracaena sanderiana Mast. & 22 & No report \\
\hline Strelitziaceae (bird of paradise family) & Strelitzia reginae Banks & 41 & No report \\
\hline Zingiberaceae (ginger family) & Elettaria cardamomum Maton & No report & 136 \\
\hline
\end{tabular}


and strong support in both maximum likelihood (Fig. 2) and Bayesian majority-rule consensus topologies (Fig. 3). Dickeya, Brenneria, and Pectobacterium spp. each form strongly supported monophyletic groups, and together they form a $100 \%$ bootstrap value-supported supergroup, which is a sister to Yersinia spp., which were used as outgroups. Brenneria and Dickeya spp. are the most closely related to each other; together, they constitute a group with much deeper-branching lineages than the group of Pectobacterium spp. This suggests that the Brenneria and Dickeya spp. represent a more ancient divergence in the evolution of soft rot and non-soft rot enterobacteria. A more comprehensive understanding of these two lineages will require analysis with a much larger strain collection.

The incongruence of our phylogenies and the trees from other studies in inferring the evolutionary relationships of soft-rotting Pectobacterium and Dickeya lineages and non-softrotting Brenneria lineages. Our phylogenies also support the emergence of a nonpectolytic necrogenic group from a-soft rotassociated lineage. It confirms the close relationship of Brenneria spp. and these soft rot enterobacteria found by others (47), although our well-supported clustering of Brenneria and Dickeya spp. is at odds with Samson et al. (112), which suggests that the Dickeya spp. are more closely related to Pectobacterium spp. and form a supergroup that is sister to Brenneria spp. Furthermore, when Brown et al. (18) examined the phylogenetic divergence of necrogenic members of Erwinia and Brenneria, their data suggest that Brenneria clades are disrupted taxonomically by several clades of soft-rotting Pectobacterium and Dickeya lineages. However, both the Brown et al. (18) and Samson et al. (112) analyses lacked strong statistical support for many of the branches in their phylogenies.

The incongruence of our data with previous studies also could be caused by one or more of the following major factors in tree inferences. A disadvantage of our study is that some of the clades (e.g., P. wasabiae Gardan et al. 2003) are underrepresented relative to other neighboring clades because we intensively sampled $P$. carotovorum Gardan et al. 2003. However, there are several advantages of our study. (i) Our strains came from a variety of plant hosts and geographical locations, and our phylogeny has the highest number of strains used in soft rot phylogenetic analysis. (ii) We used concatenated molecular markers from seven genes. The multilocus phylogenetic assessment provides a substantial amount of phylogenetically informative characters, which mitigates the shortcomings of single-gene phylogenetic inference. The previous phylogenetic studies almost exclusively relied on $16 \mathrm{~S}$ rRNA gene phylogenies. Although 16S rDNA gene sequences have several advantages, including being effectively a single-copy gene, highly conserved, and easy to amplify, these advantages are partly offset by its other properties. The $16 \mathrm{~S}$ rDNA is relatively short and contains fewer phylogenetically informative characters, and some of the variable sites tend to get saturated $(45,54,101)$. (iii) We used statistics-based algorithms which have been proven to be much more reliable than distance-based algorithms that were used in other studies. (iv) We used model-based phylogenetic analysis in this study, whereas the other studies did not. Model selection recently is considered to be a critical step in phylogenetic analysis in order to find the most suitable model of sequence evolution; it corrects for multiple substitutions at sites and is especially important for anciently divergent sequences $(45,101)$. (v) Furthermore, phylogenies selected by the topology test are in agreement with each other, demonstrating consistency in the reconstructions, and bootstrap values and posterior probabilities indicate strong confidence in the results. Both consistency and confidence yield a robust and much more reliable phylogeny. (vi) Finally, we used sequences from members of the closely related genus Yersinia as outgroups, which maximizes the likelihood of observing the most informative polarities and inferring the most recent common ancestor in our phylogenetic trees. Other studies use either more distantly related outgroups (e.g., Bacillus spp. [15] or Serratia, Enterobacter, Erwinia, and Pantoea spp. [36]), or do not use outgroups at all (112).

Pectobacterium spp. are divided into at least five clades. Within the genus Pectobacterium, there are five major clades designated I, II, III, IV, and V, which differs from previous studies. Hauben and co-workers (52) and other researchers (47) suggested that there are five subspecies or species-level clades of Pectobacterium (E. carotovorum): atrosepticum, betavasculorum Gardan 2003, carotovorum, odoriferum Gardan et al. 2003, and wasabiae. These analyses did not include clade I strains (E. carotovora subsp. brasiliensis Duart et al. 2004). Our reconstructed phylogenies agree that $P$. atrosepticum, $P$. betavasculorum, and $P$. wasabiae do form individual clades and place the brasiliensis strains in an individual clade.

The type strain for E. carotovora subsp. brasiliensis, 1692, is in clade I and, until now, this subspecies has been reported only in Brazil (39). We found that strains from both the United States and Israel were also in clade I. Over the past decades, there has been controversy over whether $P$. carotovorum, or only $P$. atrosepticum, can cause potato blackleg, which is defined as a stem necrosis extending up from a seed potato piece $(95,96)$. Perhaps some of the confusion is due to researchers not realizing that four different clades of Pectobacterium were infecting potato. Ongoing genome analyses in several laboratories should shed light on which bacterial genes are required for blackleg symptoms and the distribution of these genes among Pectobacterium strains.

Our phylogeny places $P$. carotovorum subsp. odoriferum SCRI482 with other $P$. carotovorum subsp. carotovorum inside clade II. However, our results do not support maintaining this

TABLE 4. Number of plant orders in each clade reported as hosts of Pectobacterium or Dickeya spp.

\begin{tabular}{|c|c|c|c|}
\hline Orders & Pectobacterium spp. & Dickeya spp. & Neither \\
\hline \multicolumn{4}{|l|}{ Dicots } \\
\hline Magnoliids & 1/4 (Laurales) & $0 / 4$ & 3/4 (Canellales, Magnoliales, Piperales) \\
\hline Eudicots & $0 / 2$ & $0 / 2$ & 2/2 (Proteales, Ranunculales) \\
\hline Core Eudicots & 2/4 (Saxifragales, Caryophyllales) & 2/4 (Saxifragales, Caryophyllales) & 2/4 (Gunnerales, Santalales) \\
\hline Rosids & $0 / 3$ & $1 / 3$ (Geraniales) & 2/3 (Crossosomatales, Myrtales) \\
\hline Eurosids I & 3/7 (Malpighiales, Rosales, Cucurbitales) & 3/7 (Malpighiales, Fabales, Cucurbitales) & 3/7 (Celastrales, Oxalidales, Fagales) \\
\hline Eurosids II & 1/3 (Brassicales, Malvales, Sapindales) & $0 / 3$ & $0 / 3$ \\
\hline Asterids & 1/2 (Ericales $)$ & $1 / 2$ (Ericales) & 1/2 (Cornales) \\
\hline Euasterids I & 1/4 (Solanales) & 1/4 (Solanales) & 3/4 (Garryales, Gentianales, Lamiales) \\
\hline Euasterids II & 2/4 (Apiales, Asterales) & 2/4 (Apiales, Asterales) & 2/4 (Aquifoliales, Dipsacales) \\
\hline \multicolumn{4}{|l|}{ Monocots } \\
\hline Base monocots & $\begin{array}{l}\text { 5/6 (Alismatales, Asparagales, Dioscoreales, } \\
\text { Liliales, Pandanales) }\end{array}$ & 2/6 (Alismatales, Asparagales) & 1/6 (Acorales $)$ \\
\hline Commelinids & 1/4 (Zingiberales) & 3/4 (Arecales, Poales, Zingiberales) & 1/4 (Commelinales) \\
\hline Total dicots & $11 / 33=33 \%$ & $10 / 33=30 \%$ & $18 / 33=55 \%$ \\
\hline Total monocots & $6 / 10=60 \%$ & $5 / 10=50 \%$ & $2 / 10=20 \%$ \\
\hline Total families & $16 / 43=37 \%$ & $15 / 43=35 \%$ & $21 / 43=47 \%$ \\
\hline
\end{tabular}


subspecies designation because the level of divergence of SCRI482 from other clade II strains is similar to or less than that seen within other clades, such as the $P$. atrosepticum and $P$. wasabiae clades. Conspicuously, our data indicate that the strains that had been classified as E. carotovora subsp. carotovora based on biochemical tests (146) do not form a monophyletic group. Rather, these strains, which are designated by WPP names, are spread among clades I, II, and III.
The clade III strains include $P$. wasabiae SCRI 488 and several strains from potato tubers. Curiously, based on PCR and DNA hybridization results, nearly all of the clade III strains, including WPP161, WPP163, WPP168, WPP172, and SCRI 488, lack the type III secretion system (T3SS) (H.-S. Kim, unpublished data). The T3SS is a protein secretion system found in many gramnegative pathogens where it is used to inject virulence proteins directly into host cells. Once inside, the virulence proteins

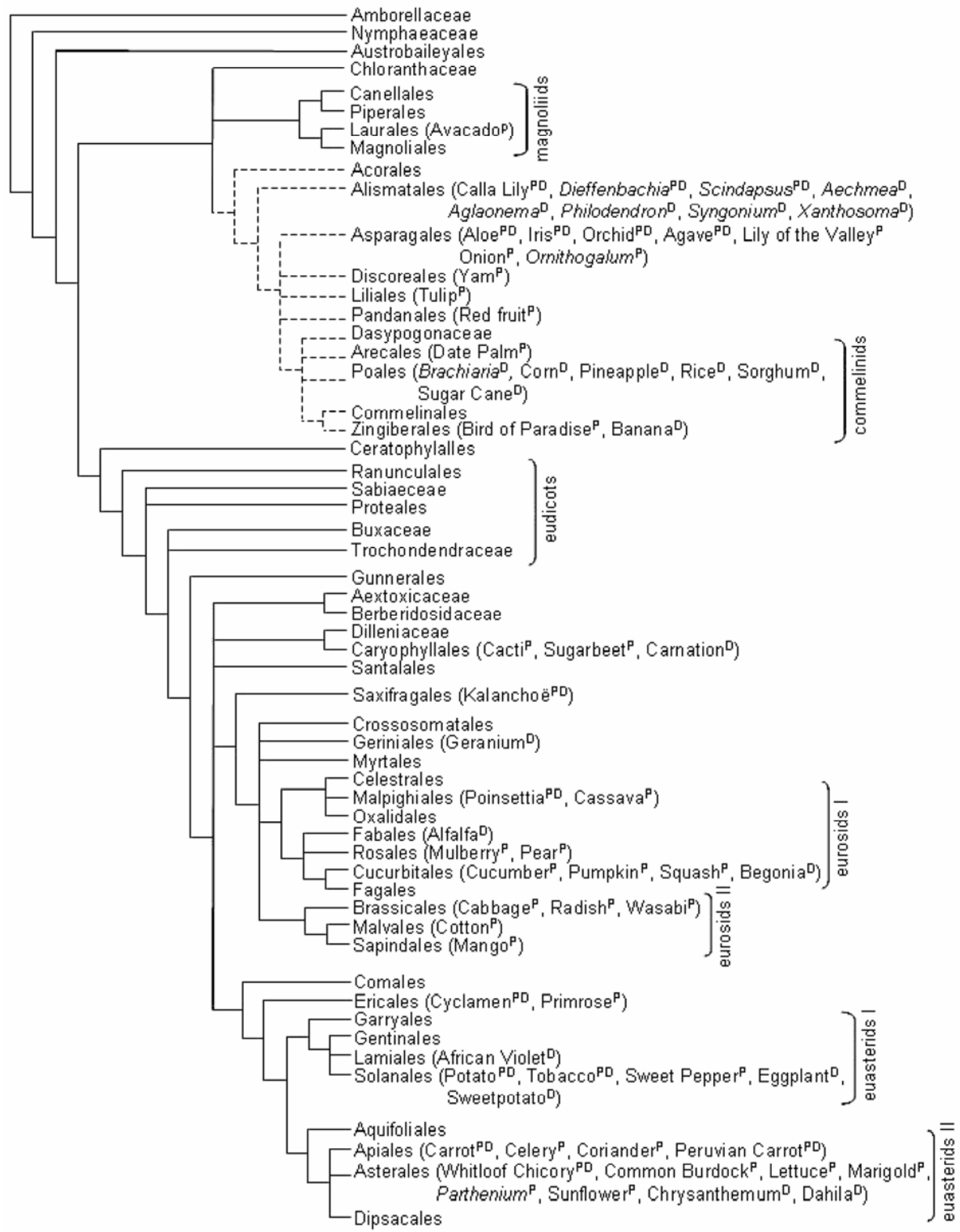

Fig. 1. Phylogenetic tree of angiosperms adapted from Bremer et al. (15) showing the reported hosts for Pectobacterium and Dickeya spp. The dotted lines denote monocot families. Pectobacterium and Dickeya hosts are indicated by a superscript "P" or "D," respectively. Plant clades are indicated with brackets on the right side of the tree. 
TABLE 5. Informativeness indicators for the sequenced gene fragments ${ }^{\mathrm{a}}$

\begin{tabular}{|c|c|c|c|c|c|c|c|c|}
\hline Data set & $\begin{array}{l}\text { No. of } \\
\text { taxa }\end{array}$ & $\begin{array}{c}\text { No. of } \\
\text { characters }\end{array}$ & $\begin{array}{c}\text { Parsimony-informative } \\
\text { characters }\end{array}$ & $\begin{array}{c}\text { No. of constant } \\
\text { characters }\end{array}$ & RC index & f value & f ratio & HI \\
\hline $\operatorname{acn} A$ & 53 & 288 & 132 & 146 & 0.61 & 9,920 & 0.85 & 0.32 \\
\hline gapA & 53 & 330 & 103 & 307 & 0.39 & 13,340 & 0.68 & 0.52 \\
\hline$i c d A$ & 53 & 499 & 143 & 332 & 0.42 & 15,950 & 0.49 & 0.49 \\
\hline$m d h$ & 53 & 440 & 167 & 247 & 0.43 & 9,980 & 0.31 & 0.48 \\
\hline$m t I D$ & 53 & 386 & 177 & 179 & 0.50 & 14,240 & 0.44 & 0.42 \\
\hline$p g i$ & 51 & 501 & 173 & 300 & 0.42 & 19,580 & 0.51 & 0.50 \\
\hline proA & 51 & 628 & 320 & 290 & 0.35 & 29,070 & 0.52 & 0.55 \\
\hline
\end{tabular}

a Rescaled consistency (RC), f value, f ratio, and homoplasy index (HI) were implemented in PAUP* $4.0 b 10$ according to Farris (44).

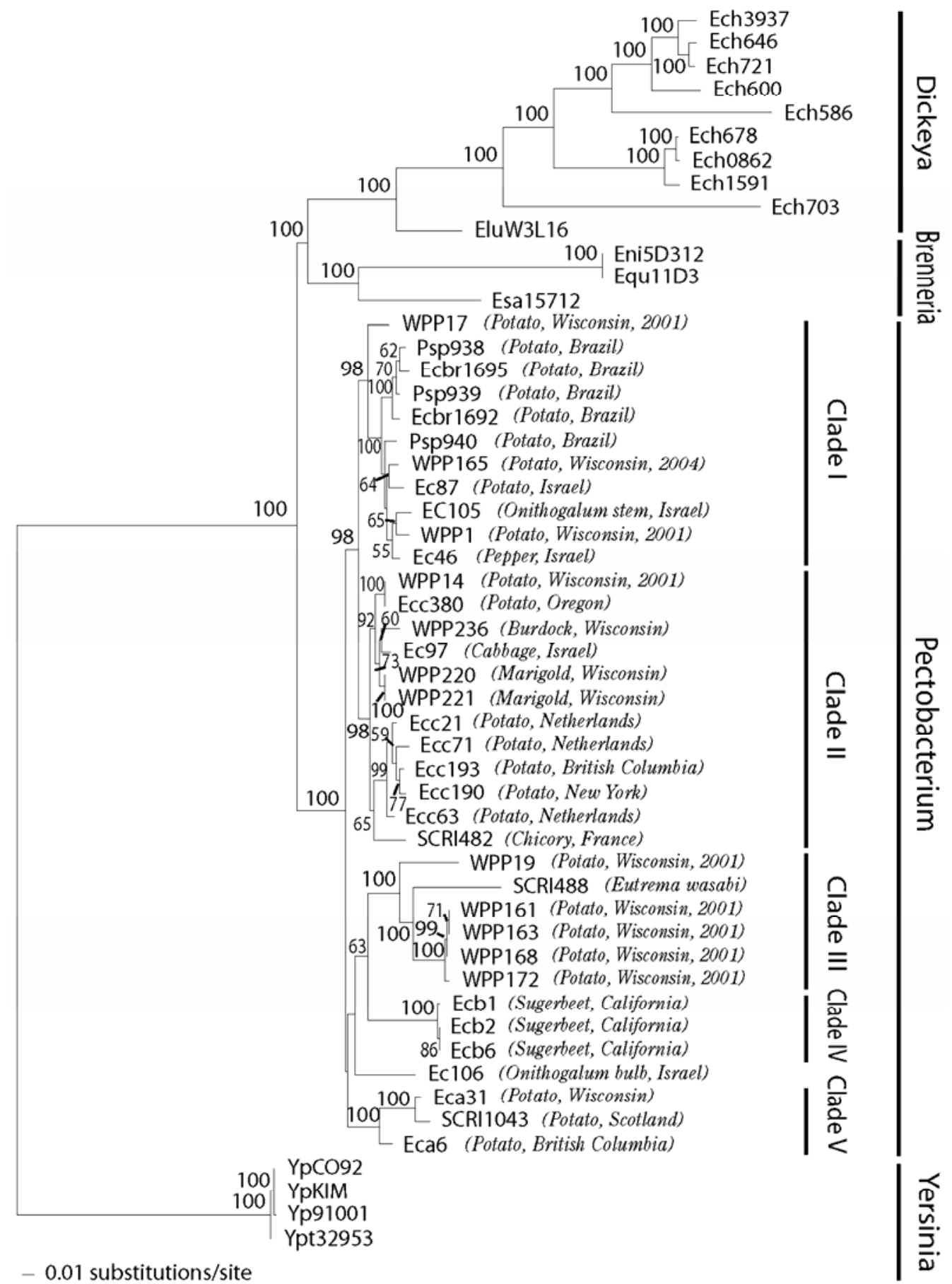

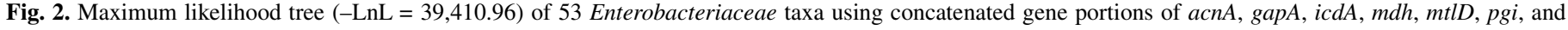

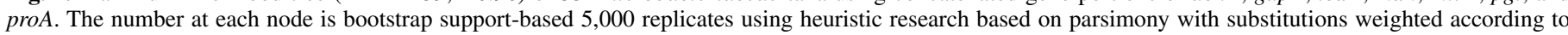

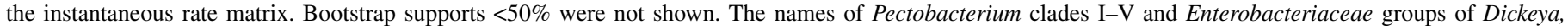

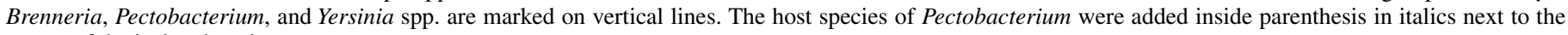
names of the isolated strains. 
suppress host cell defenses. WPP19, which is at the base of clade III, has an atypical T3SS (146). In 2001, we isolated an atypical Pectobacterium strain from potato, WPP17, and found that it lacked the T3SS (146). However, WPP17 is not in clade III, suggesting that multiple losses of the T3SS have occurred. So far, T3SS-minus strains have been isolated only from potato and wasabi (Eutrema wasabi Maxim.); thus, we cannot determine whether the T3SS is required for Pectobacterium spp. to cause disease in other hosts. Experiments are ongoing to determine whether clade III strains use mechanisms analogous to the T3SS to suppress plant defenses or, alternatively, if clade III strains are unable to suppress plant defense responses.

There is an orphan taxon, Ec106, which was isolated from an Ornithogalum bulb, located between clades IV and V, which does not group with any other Pectobacterium spp. Another strain, Ec105, isolated from the stem of the same plant species, grouped firmly with other Pectobacterium spp. inside clade I. There are likely additional members of the "Ec106 clade" among the soft

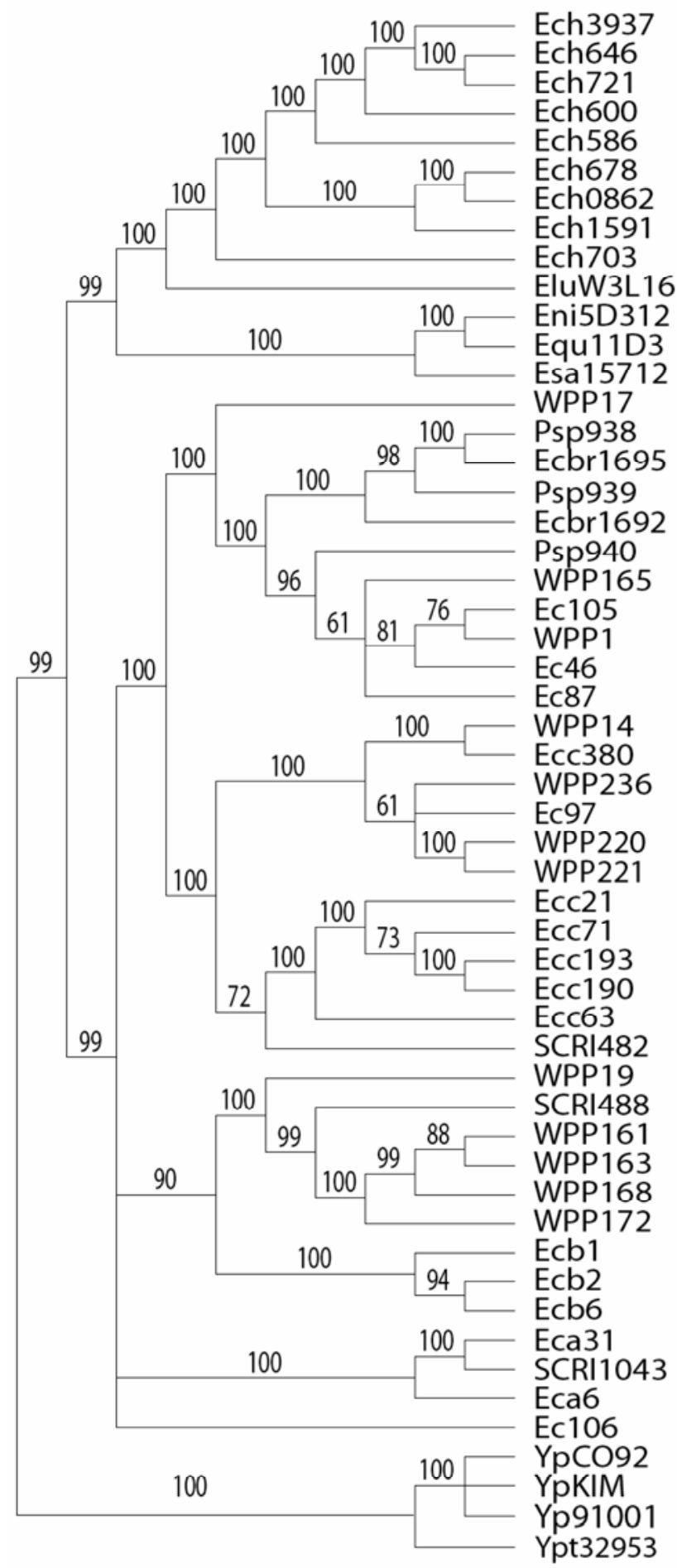

(Potato, Wisconsin, 2001)

(Potato, Brazil)

(Potato, Brazil)

(Potato, Brazil)

(Potato, Brazil)

(Potato, Brazil)

(Potato, Wisconsin, 2004)

(Ornithogalum stem, Israel)

(Potato, Wisconsin, 2001)

(Pepper, Brazil)

(Potato, Israel)

(Potato, Wisconsin, 2001)

(Potato, Oregon)

(Burdock, Wisconsin)

(Cabbage, Israel)

(Marigold, Wisconsin)

(Marigold, Wisconsin)

(Potato, Netherlands)

(Potato, Netherlands)

(Potato, British Columbia)

(Potato, New York)

(Chicory, France)

(Potato, Wisconsin, 2001)

(Eutrema wasabi)

(Potato, Wisconsin, 2001)

(Potato, Wisconsin, 2001)

(Potato, Wisconsin, 2001)

(Potato, Wisconsin, 2001)

(Sugerbeet, California)

(Sugerbeet, California)

(Sugerbeet, California)

(Ornithogalum bulb, Israel)

(Potato, Wisconsin)

(Potato, Scotland)

(Potato, British Columbia)
(Potato, Netherlands)

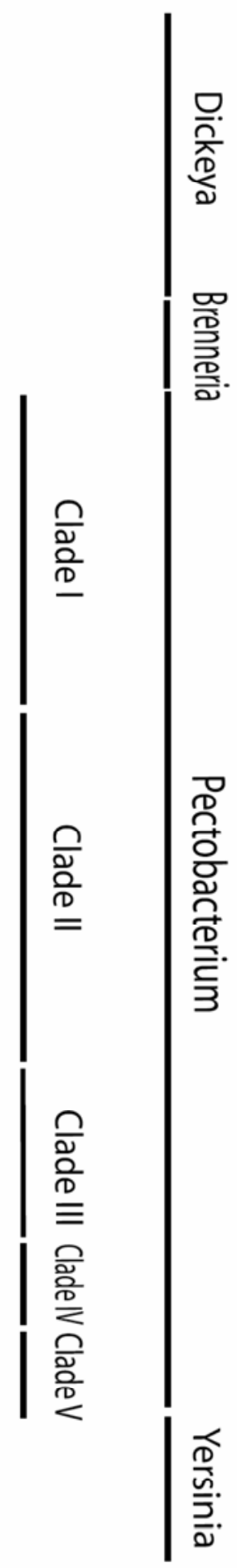

Fig. 3. Bayesian phylogeny of 53 Enterobacteriaceae taxa using concatenated gene portions of acnA, gapA, icdA, $m d h, m t l D, p g i$, and proA. Each run contained four chains starting from random trees, and 5,000,000 generations with trees sampled at every 100 generations. The majority rule consensus tree was calculated after removal of the first 500 trees that were saved during burn-in period. The number at each node is posterior probabilities Bayesian produced. The names of Pectobacterium clades I-V and Enterobacteriaceae groups of Dickeya, Brenneria, Pectobacterium, and Yersinia spp. are marked on vertical lines. The host species of the Pectobacterium strains are in parentheses in italics next to the strain designations. 
rot enterobacteria that remain undetected because our taxon sampling was not comprehensive. A more thorough sampling of monocot strains is likely to reveal additional members of this clade. Clades IV and V comprise two Pectobacterium spp. with narrow host ranges, with $P$. betavasculorum infecting mainly sugar beet and $P$. atrosepticum infecting potato.

Pectobacterium spp. have been divided into multiple serogroups $(32,34)$ and representatives of several of these serogroups were included in our data set. $P$. carotovorum serogroups 3 (Ecc71) and 29 (Ecc380), which are commonly found on diseased potato (84), and serogroups 9 (Ecc63) and 11 (Ecc193), which have been reported to be more common on symptomless potato (32), all were placed in clade II. Two P. atrosepticum serogroups, 1 (Eca31) and 18 (Eca6), also were included in our data set. The phylogenetic distance between the two $P$. atrosepticum serogroups is similar to that between some of the $P$. carotovorum serogroups, suggesting that there has been a similar amount of divergence among clade II and clade V strains.

Multiple Pectobacterium lineages are broad-host-range pathogens. We found that strains isolated from the same host can be located in different clades. For example, Pectobacterium spp. causing disease in potato are distributed in four clades and do not form a monophyletic group. We also found that strains isolated from different plant hosts can be grouped together paraphyletically, which suggests that the Pectobacterium clades I, II, and III have broad host ranges. For example, strains within clade II were isolated from potato (WPP14), marigold (WPP220 and WPP221), cabbage (RS3/91), burdock (WPP236), and chicory (SCRI 482). Noticeably, some potato strains collected in different years and in widely different locations are grouped closely with each other, whereas potato strains obtained from a single field may fall into multiple clades. For example, within the well-supported clade I, the potato strains are closely related to each other, although these strains were collected at different locations, including Wisconsin, Brazil, and Israel. Similarly, strains from clade II also have worldwide distribution, originating in the United States, the Netherlands, Israel, British Columbia, and France. Compared with other clades of Pectobacterium, clade I and II have much shallower branches, which suggest that their descendents are more recently evolved lineages. In addition, the Dickeya spp. have deep branches compared with the Pectobacterium spp. Therefore, our data do not support a correlation between clade diversity and host range breadth.

Our analyses show that the genera Dickeya and Pectobacterium contain broad-host-range pathogens that, together, cause disease in half of the angiosperm plant orders, and the lineages of Dickeya spp. have evolved over a longer time than the Pectobacterium spp. There are some host range limitations associated with subgroups of both genera. For example, two clades of Pectobacterium, $P$. atrosepticum, and $P$. betavasculorum, have been reported on only a limited number of plant species, and Pectobacterium spp., unlike Dickeya spp., have not yet been reported to cause disease in grain species.

In contrast, Brenneria spp. have a more limited host range, causing disease only in woody plants in the eurosids I clade, including the Fagales trees oak (Quercus spp. L.), walnut (Juglans spp. L.), and Malpighiales tree willow (Salix spp. L.). Strain EluW3L16, which is placed at the base of the Dickeya clade, also was isolated from a eurosids I clade host, Lupinus spp. L., which is in the Fabales. Our data support the emergence of the necrogenic genus Brenneria from the soft rot enterobacteria. Like the genus Dickeya, the genus Brenneria consists of a more ancient group than the genus Pectobacterium. This suggests that the progenitor of the genus Brenneria may have gained the abilities to cause disease in tree species, none of which have been reported as hosts for species of the genera Pectobacterium or Dickeya; and, perhaps subsequently, the genus Brenneria lost genes encoding pectinases. More insight awaits further information on which bac- terial virulence genes are required to cause disease in trees, possibly through a genome-wide comparison of Brenneria spp. and Erwinia amylovora, which may have evolved independently as necrogenic tree pathogens.

Our analysis divides the genus Pectobacterium into five clades, three of which include strains isolated from multiple hosts. One of the strains, Ec106, was not placed into any clade; thus, there are likely to be additional Pectobacterium clades. Our analysis supports the hypothesis that the ancestor of the genus Pectobacterium was a broad-host-range pathogen and demonstrates that strains isolated from the same host plant, whether it is potato or Ornithogalum spp., are not necessarily closely related. The apparently narrow host ranges of $P$. atrosepticum and $P$. betavasculorum suggests that these species have acquired genes that limit their host range or have lost genes required to cause disease in a diverse range of host plants.

The concatenated data set used for this analysis provides robust insight into evolution of the soft rot enterobacteria and a strongly supported framework into which newly isolated Pectobacterium, Dickeya, or Brenneria strains can be placed using technologies available to most microbiology laboratories. Because the seven genes chosen for this analysis are present in nearly all enterobacteria, this data set also can be used as a basis for determining the relationships of other enterobacterial genera to these plant pathogens and to each other. Traditionally, DNA hybridization assays have been an important tool in designating new species and these assays played an important role in earlier characterization of soft rot enterobacteria $(16,17)$. However, with the advent of new sequencing technologies (85), we predict that full genome sequence comparisons will become a standard method for defining bacterial species. Multilocus phylogenetic analysis is likely to remain an important tool because it is relatively rapid and inexpensive and, as demonstrated here and elsewhere (100), it provides enough informative characters for robust phylogenies.

\section{ACKNOWLEDGMENTS}

This work was supported by funding from the University of Wisconsin Graduate School, National Science Foundation grant 0412599, and the Wisconsin Potato and Vegetable Growers Association. This project made use of preliminary sequences from the Erwinia chyrsanthemi 3937 genome project supported by Initiative for Future Agriculture and Food Systems Grant no. 2001-52100-11316 from the United States Department of Agriculture Cooperative State Research, Education, and Extension Service to N. T. Perna. B. Ma and M. E. Hibbing contributed equally to this work.

\section{LITERATURE CITED}

1. Abdalla, M. Y. 2001. Sudden decline of date palm trees caused by Erwinia chrysanthemi. Plant Dis. 85:24-26.

2. Alcorn, S. M., and Orum, T. V. 1988. Rejection of the names Erwinia carnegieana Standring 1942 and Pectobacterium carnegieana (Standring 1942) Brenner, Steigerwalt, Miklos and Fanning 1973. Int. J. Syst. Bacteriol. 38:132-134.

3. Alcorn, S. M., Orum, T. V., Steigerwalt, A. G., Foster, J. L., Fogleman, J. C., and Brenner, D. J. 1991. Taxonomy and pathogenicity of Erwinia cacticida sp. nov. Int. J. Syst. Bacteriol. 41:197-212.

4. Alivizatos, A. S. 1985. Bacterial wilt of tomato in Greece caused by Erwinia chrysanthemi. Plant Pathol. 34:638-639.

5. Amusa, N. A., and Baiyewu, R. A. 1999. Storage and market disease of yam tubers in southwestern Nigeria. Ogun. J. Agric. Res. (Niger.) 11:211225.

6. Appel, O. 1903. Untersuchuungen uber die scharzbeinigkeit und die durch bakterien hervorgerufene knollenfaule der kartoffeln. Arb. Biol. Abt. K. Gsndhtsamt. 3:365-432.

7. Ark, P. A., Starr, M. P., and Sutton, D. D. 1952. Bacterial chalk rot of yellow and pink callas. Phytopathology 42:320-322.

8. Ark, P. A., and Tompkins, C. M. 1946. Soft rot of leaves and flowers of yellow calla (Zantedeschia elliottiana) caused by Erwinia carotovora. U. S. Dep. Agric. Plant Dis. Rep. 30:32.

9. Arsenijevic, M. 1970. A bacterial soft rot of sunflower. Acta Phytopathol. Acad. Sci. Hung. 5:317-326. 
10. Arsenijevic, M., and Sojic, J. 1972. Investigation of pathogenicity of some bacterial isolates from the species Erwinia carotovora (Jones) Holland. Zast. Bilja 23:183-192.

11. Avrova, A. O., Hyman, L. J., Toth, R. L., and Toth, I. K. 2002. Application of amplified fragment length polymorphism fingerprinting for taxonomy and identification of the soft rot bacteria Erwinia carotovora and Erwinia chrysanthemi. Appl. Environ. Microbiol. 68:1499-1508.

12. Bell, K. S., Sebaihia, M., Pritchard, L., Holden, M. T. G., Hyman, L. J., Holeva, M. C., Thomson, N. R., Bentley, S. D., Churcher, L. J. C., Mungall, K., Atkin, R., Bason, N., Brooks, K., Chillingworth, T., Clark, K., Doggett, J., Fraser, A., Hance, Z., Hauser, H., Jagels, K., Moule, S., Norbertczak, H., Ormond, D., Price, C., Quail, M. A., Sanders, M., Walker, D., Whitehead, S., Salmond, G. P. C., Birch, P. R. J., Parkhill, J., and Toth, I. K. 2004. Genome sequence of the enterobacterial phytopathogen Erwinia carotovora subsp. atroseptica and characterization of virulence factors. Proc. Natl. Acad. Sci. USA 101:11105-11110.

13. Bereau, M., and Samson, R. 1981. Une pourriture bacterienne sure graminee fourragere tropicale. Agronomie 1:273-276.

14. Boyraz, N., Bastas, K. K., Maden, S., and Yasar, A. 2006. Bacterial leaf and peduncle soft rot caused by Pectobacterium carotovorum on tulips in Konya, Turkey. Phytoparasitica 34:272-280.

15. Bremer, B., Bremer, K., Chase, M. W., Reveal, J. L., Soltis, D. E., Soltis, P. S., Stevens, P. F., Anderberg, A. A., Fay, M. F., Goldblatt, P., Judd, W. S., Kallersjo, M., Karehed, J., Kron, K. A., Lundberg, J., Nickrent, D. L., Olmstead, R. G., Oxelman, B., Pires, J. C., Rodman, J. E., Rudall, P. J., Savolainen, V., Systma, K. J., van der Bank, M., Wurdack, K., Xiang, J. Q.-Y., and Zmarzty, S. 2003. An update of the Angiosperm Phylogeny Group classification for the orders and families of flowering plants: APG II. Bot. J. Linn. Soc. 141:399-436.

16. Brenner, D. J., Fanning, G. R., and Steigerwalt, A. G. 1974. Deoxyribonucleic acid relatedness among erwiniae and other Enterobacteriaceae: The gall, wilt, and dry necrosis organisms (Genus Erwinia Winslow et al. sensu stricto). Int. J. Syst. Bacteriol. 24:197-204.

17. Brenner, D. J., Fanning, G. R., and Steigerwalt, A. G. 1977. Deoxyribonucleic acid relatedness among erwiniae and other enterobacteria II. corn stalk rot bacterium and Pectobacterium chrysanthemi. Int. J. Syst. Bacteriol. 27:211-221

18. Brown, E. W., Davis, R. M., Gouk, C., and van der Zwet, T. 2000. Phylogenetic relationships of necrogenic Erwinia and Brenneria species as revealed by glyceraldehyde-3-phosphate dehydrogenase gene sequences. Int. J. Syst. Evol. Microbiol. 50:2057-2068.

19. Burkholder, W. H., McFadden, L. A., and Dimock, A. W. 1953. A bacterial blight of chrysanthemums. Phytopathology 43:522-526.

20. Burton, C. L. 1970. Disease of tropical vegetables on the Chicago market. Trop. Agric. Trinidad 47:303-313.

21. Chakravarti, B. P., and Rangarajan, M. 1966. Occurrence of Erwinia aroideae on two new hosts in India. Plant Dis. Rep. 50:701-702.

22. Chase, A. R., and Brunk, D. D. 1984. Leaf spot of Dracaena sanderana caused by two species of Erwinia. Plant Dis. 68:251.

23. Chatterjee, A., Cui, Y. Y., and Chatterjee, A. K. 2002. Regulation of Erwinia carotovora hrpL(Ecc) (sigma-L-Ecc), which encodes an extracytoplasmic function subfamily of sigma factor required for expression of the HRP regulon. Mol. Plant-Microbe Interact. 15:971-980.

24. Chatterjee, A., Cui, Y., Chaudhuri, S., and Chatterjee, A. K. 2002. Identification of regulators of hrp/hop genes of Erwinia carotovora ssp. carotovora and characterization of $\operatorname{HrpL}(\mathrm{Ecc})(\operatorname{SigmaL}(\mathrm{Ecc}))$, an alternative sigma factor. Mol. Plant Pathol. 3:359-370.

25. Chester, F. D. 1937. A bacterial disease of Delphinium. Phytopathology 27:855-858.

26. Citinkaya-Yildiz, R., Mirik, M., Aysan, Y, and Kusek, M. 2004. An outbreak of bacterial stem rot of Dieffenbachia amoena caused by Erwinia carotovora subsp. carotovora in the Eastern Mediterranean region of Turkey. Plant Dis. 88:310.

27. Cognee, M., and Frinking, H. D. 1966. Role de quelques bacteries dans le developpment des pourritures secondairs de capsules du contonnier. Coton Fibres Trop. 21:250-261.

28. Comelli, R., and Cavalli, M. 1976. Erwinia chrysanthemi associated with leaf rot in Aechmea fasciata. Inf. Fitopatol. 4:21-23.

29. Cui, Y., Chatterjee, A., and Chatterjee, A. K. 2001. Effects of the twocomponent system comprising GacA and GacS of Erwinia carotovora subsp. carotovora on the production of global regulatory rsmB RNA, extracellular enzymes, and Harpin(Ecc). Mol. Plant-Microbe Interact. 14:516-526.

30. Daniel, J.-F., Boher, B., and Kohler, F. 1981. Bacterial pathogens of cassava in the People's Republic of the Congo and the Central African Republic. Agronomie 1:751-758.

31. Darrasse, A., Priou, S., Kotoujansky, A., and Bertheau, Y. 1994. PCR and restriction fragment length polymorphism of a pel gene as a tool to identify Erwinia carotovora in relation to potato diseases. Appl. Environ. Microbiol. 60:1437-1443.
32. De Boer, S. H., Copeman, R. J., and Vruggink, H. 1979. Serogroups of Erwinia carotovora potato strains determined with diffusible somatic antigens. Phytopathology 69:316-319.

33. De Boer, S. H., and Kelman, A. 2001. Erwinia soft rot group. In: Laboratory Guide for Identification of Plant Pathogenic Bacteria. N. W. Schaad, J. B. Jones, and W. Chun, eds. American Phytopathological Society, St. Paul, MN.

34. De Boer, S. H., and Sasser, M. 1986. Differentiation of Erwinia carotovora subsp. carotovora and E. carotovora subsp. atroseptica on the basis of cellular fatty acid composition. Can. J. Microbiol. 32:796-800.

35. De Laat, P. C. A., Verhoeven, J. T. W., and Janse, J. D. 1994. Bacterial leaf rot of Aloe vera L., caused by Erwinia chrysanthemi biovar 3. Eur. J. Plant Pathol. 10:81-84.

36. Dickey, R. S., and Victoria, J. I. 1980. Taxonomy and emended description of strains of Erwinia isolated from Musa paradisiaca Linnaeus. Int. J. Syst. Bacteriol. 30:129-134.

37. Dinesen, I. G. 1979. A disease of Kalanchoë blossfeldiana caused by Erwinia chrysanthemi. Phytopathol. Z. 95:59-64.

38. Dowson, W. J., and Hayward, A. C. 1960. The bacterial mottle pathogen of Queensland sugar cane. Int. Sugar J. 62:275.

39. Duarte, V., De Boer, S. H., Ward, L. J., and de Oliveira, M. C. 2004. Characterization of atypical Erwinia carotovora strains causing blackleg of potato in Brazil. J. Appl. Microbiol. 96:535-545.

40. Dye, D. W. 1969. A taxonomic study of genus Erwinia. II. The carotovora group. N. Z. J. Sci. 12:590-607.

41. El-Goorani, M. A., and Abo-El-Dahab, M. K. 1972. Root rot of Strelitzia reginae Banks caused by Erwinia carotovora (Jones) Holland. Egypt. J. Phytopathol. 4:65-70.

42. El Tassa, S. O. M., and Duarte, V. 2006. Identificação de Pectobacterium carotovorum subsp. brasiliensis através de PCR-RFLP do gene recA. Fitopathol. Bras. 31:23-28.

43. Engelhard, A. W., McGuire, R. G., and Jones, J. B. 1986. Erwinia carotovora pv. carotovora, a pathogen of Kalanchoe blossfeldiana. Plant Dis. 70:575-577.

44. Farris, J. S. 1972. Estimating phylogenetic trees from distance matrices. Am. Nat. 106:645-668.

45. Felsenstein, J. 2004. Inferring Phylogenies. Sinauer Associates, Inc., Sunderland, MA.

46. Gallois, A., Samson, R., Ageron, E., and Grimont, P. A. D. 1992. Erwinia carotovora subsp. odorifera subsp. nov., associated with odorous soft rot of chicory (Cichorium intybus L.). Int. J. Syst. Bacteriol. 42:582-588.

47. Gardan, L., Gouy, C., Christen, R., and Samson, R. 2003. Elevation of three subspecies of Pectobacterium carotovorum to species level: Pectobacterium atrosepticum sp. nov., Pectobacterium betavasculorum sp. nov. and Pectobacterium wasabiae sp. nov. Int. J. Syst. Evol. Microbiol. 53:381-391.

48. Goldman, N., Anderson, J. P., and Rodrigo, A. G. 2000. Likelihood-based tests of topologies in phylogenetics. Syst. Biol. 49:652-670.

49. Goto, M. 1979. Bacterial foot rot of rice caused by a strain of Erwinia chrysanthemi. Phytopathology 69:213-216.

50. Goto, M., and Matsumoto, K. 1987. Erwinia carotovora subsp. wasabiae subsp. no. isolated from diseased rhizomes and fibrous roots of Japanese horseradish (Eutrema wasabi Maxim.). Int. J. Syst. Bacteriol. 37:130-135.

51. Guevara, Y. M., Rondon, A. G., and Solorzano, R. 1980. Bacteriosis del mango (Mangifera indica L.) en Venezualea I. Sintomatologia e identifcacion. Agron. Trop. 30:65-76.

52. Hauben, L., Moore, E. R. B., Vauterin, L., Steenackers, M., Mergaert, J., Verdonck, L., and Swings, J. 1998. Phylogenetic position of phytopathogens within the Enterobacteriaceae. Syst. Appl. Microbiol. 21:384-397.

53. Henz, G. P., Reifschneider, F. J. B., and Duarte, V. 2006. Erwinia chrysanthemi: Pectolytic bacterium causing soft rot outbreaks of arracacha in Brazil. Pesqui. Agropecu. Bras. 41:1567-1571.

54. Hillis, D. M., Moritz, C., and Mable, B. K. 1996. Molecular Systematics, 2nd ed. Sinauer Associates, Sunderland, MA.

55. Hoitink, H. A. J., and Daft, G. C. 1972. Bacterial stem rot of poinsettia, a new disease caused by Erwinia carotovora var. chrysanthemi. Plant Dis. Rep. 56:480-484.

56. Holdeman, Q. L., and Burkholder, W. H. 1956. The identity of barn rots of flue-cured tobacco in South Carolina. Phytopathology 46:69-72.

57. Hoppe, P. E., and Kelman, A. 1969. Bacterial top and stalk rot disease of corn in Wisconsin. Plant Dis. Rep. 53:66-70.

58. Howard, C. M., and Leach, J. G. 1963. Relation of the iris borer to bacterial soft rot of iris. Phytopathology 53:1190-1193.

59. Huelsenbeck, J. P., and Bollback, J. P. 2001. Empirical and hierarchical Bayesian estimation of ancestral states. Syst. Biol. 50:351-66.

60. Huelsenbeck, J. P., and Ronquist, F. 2001. MRBAYES: Bayesian inference of phylogenetic trees. Bioinformatics 17:754-755.

61. Huelsenbeck, J. P., Ronquist, F., Nielsen, R., and Bollback, J. P. 2001. Bayesian inference of phylogeny and its impact on evolutionary biology. Science 294:2310-2314. 
62. Hunter, R. E. 1968. A boll rot of cotton caused by Erwinia aroideae. Plant Dis. Rep. 52:14-16.

63. Jensen, S. G., Mayberry, W. R., and Obrigawitch, J. A. 1986. Identification of Erwinia chrysanthemi as a soft-rot-inducing pathogen of grain sorghum. Plant Dis. 70:593-596.

64. Jimenez-Hildago, I., Virgen-Calleros, G., Martinez de la Vega, O., Vandemark, G., and Olalde-Portugal, V. 2004. Identification and characterization of bacteria causing soft-rot in Agave tequilana. Eur. J. Plant Pathol. 110:317-331.

65. Jin, K.-S., Lee, S.-W., Kim, J.-J., and Ryu, H.-Y. 1994. Identification of bacterial isolates obtained from diseased orchid and aloe plants caused by Erwinia chrysanthemi. RDA. J. Agric. Sci. 36:301-306.

66. Jones, L. R. 1900. A soft rot of carrot and other vegetables caused by Bacillus carotovorus Jones. Vt. Agric. Exp. Stn. Rep. 13:299-332.

67. Jones, L. R. 1901. Bacillus carotovorus n. sp., die ursache einer weichen faulnis der mohre. Zbl. Bakt. (Abt. II) 7:12-21, 61-68.

68. Kang, H. W., Kwon, S. W., and Go, S. J. 2003. PCR-based specific and sensitive detection of Pectobacterium carotovorum ssp. carotovorum by primers generated from a URP-PCR fingerprinting-derived polymorphic band. Plant Pathol. 52:127-133.

69. Kelman, A., Person, L. H., and Hebert, T. T. 1957. A bacterial stalk rot of irrigated corn in North Carolina. Plant Dis. Rep. 41:798-802.

70. Khan, A. A., Furuya, N., Ura, H., and Matsuyama, N. 2000. Rapid identification of Erwinia chrysanthemi isolated from soft rotted eggplant and Phalaenopsis sp. by lipid and fatty acid profiling. J. Fac. Agric. Kyushu Univ. 44:257-263.

71. Knauss, J. F., and Miller, J. W. 1972. Description and control of the rapid decay of Scindapsus aureus incited by Erwinia carotovora. Proc. Fla. State Hortic. Soc. 85:348-352.

72. Knauss, J. F., and Wehlburg, C. 1969. The distribution and pathogenicity of Erwinia chrysanthemi Burkholder, et al. to Syngonium podophyllum Schott. Proc. Fla. State Hortic. Soc. 82:370-373.

73. Lacy, G. H., Hirano, S. S., Victoria, J. I., Kelman, A., and Upper, C. D. 1979. Inhibition of soft-rotting Erwinia spp. strains by 2,4-dihydroxy-7methoxy-2H-1,4-benzoxazin-3(4H)-one in relation to their pathogenicity on Zea mays. Phytopathology 69:757-763.

74. Lacy, G. H., Lambe, R. C., and Berg, C. M. 1981. Iris soft rot caused by Erwinia chrysanthemi, associated with overhead irrigation and its control by chlorination. Int. Plant Propagators' Soc. Combined Proc. 31:624.

75. Lai, M., Shaffer, S., and Sims, K. 1978. Bacterial blight of Syngonium podophyllum caused by Erwinia chrysanthemi in California. Plant Dis. Rep. 62:298-302.

76. Lee, Y.-A., Chen, K.-P., and Chang, H. 2002. First report of bacterial soft rot of white flowered calla lily caused by Erwinia chrysanthemi in Taiwan. Plant Dis. 86:1273.

77. LeGuern, J., Tirilly, Y., Lepicard, D., and Lester, D. 1992. Bacterial rot of witloof chicory roots caused by Erwinia chrysanthemi. Plant Pathol. 41:228-231.

78. Lelliott, R. A. 1956. Slow wilt of carnations caused by a species of Erwinia. Plant Pathol. 5:19-24.

79. Lemattre, M., and Narcy, J. P. 1972. Une infection bacterienne nouvelle du Saintpaulia due a Erwinia chrysanthemi. C. R. Acad. Sci. 58:227-231.

80. Lightle, P. C., Standring, E. T., and Brown, J. G. 1942. A bacterial necrosis of the giant cactus. Phytopathology 32:303-313.

81. Lim, W. H. 1974. The etiology of fruit collapse and bacterial heart rot of pineapple. MARDI Res. Bull. 2:11-16.

82. Limber, D. P., and Friedman, B. A. 1943. Erwinia carotovora, the cause of a soft rot of orchids, Cattleya sp. Phytopathology 33:80-82.

83. Liu, Y., Cui, Y., Mukherjee, A., and Chatterjee, A. K. 1997. Activation of the Erwinia carotovora subsp. carotovora pectin lyase structural gene pnlA: A role for RdgB. Microbiology 143:705-712.

84. Maher, E. A., Deboer, S. H., and Kelman, A. 1986. Serogroups of Erwinia carotovora involved in systemic infection of potato plants and infestation of progeny tubers. Am. Potato J. 63:1-11.

85. Margulies, M., Egholm, M., Altman, W. E., Attiya, S., Bader, J. S., Bemben, L. A., Berka, J., Braverman, M. S., Chen, Y. J., Chen, Z. T., Dewell, S. B., Du, L., Fierro, J. M., Gomes, X. V., Godwin, B. C., He, W., Helgesen, S., Ho, C. H., Irzyk, G. P., Jando, S. C., Alenquer, M. L. I., Jarvie, T. P., Jirage, K. B., Kim, J. B., Knight, J. R., Lanza, J. R., Leamon, J. H., Lefkowitz, S. M., Lei, M., Li, J., Lohman, K. L., Lu, H., Makhijani, V. B., McDade, K. E., McKenna, M. P., Myers, E. W., Nickerson, E., Nobile, J. R., Plant, R., Puc, B. P., Ronan, M. T., Roth, G. T., Sarkis, G. J., Simons, J. F., Simpson, J. W., Srinivasan, M., Tartaro, K. R., Tomasz, A., Vogt, K. A., Volkmer, G. A., Wang, S. H., Wang, Y., Weiner, M. P., Yu, P. G., Begley, R. F., and Rothberg, J. M. 2005. Genome sequencing in microfabricated high-density picolitre reactors. Nature 437:376-380

86. Martins, J. M. S. 1981. Bacterial diseases of ornamental plants in Portugal. II. Orchid diseases caused by Erwiniae of the carotovora group. Agron. Inst. 41:59-66.
87. Massey, A. B. 1924. A study of Bacillus aroideae, Townsend, the cause of a soft rot of tomato, and B. carotovorus Jones. Phytopathology $14: 460-477$

88. Mazzuchi, U. 1970. L'avvizzimento batterico della Margherita (Chrysanthemum maximum Ram.). Phytopathol. Mediterr. 9:111-121.

89. McCarter, S. M., and Moody, E. H. 1988. A wilt and crown rot of Primula species caused by Erwinia carotovora subsp. carotovora. Plant Dis. 72:672-675.

90. McCarter-Zorner, N. J., Harrison, M. D., Franc, G. D., Quinn, C. E., Sells, I. A., and Graham, D. C. 1985. Soft rot Erwinia bacteria in the rhizosphere of weeds and crop plants in Colorado, United States and Scotland. J. Appl. Bacteriol. 59:357-368.

91. McFadden, L. A. 1961. Bacterial stem and leaf rot of Dieffenbachia in Florida. Phytopathology 51:663-667.

92. McFadden, L. A. 1969. Aglaonema pictum, a new host of Erwinia chrysanthemi. Plant Dis. Rep. 53:253-254.

93. Meneley, J. C., and E., Stanghellini, M. 1975. Establishment of an inactive population of Erwinia carotovora in healthy cucumber fruit. Phytopathology 65:670-673.

94. Miller, H. N., and McFadden, L. A. 1961. A bacterial disease of philodendron. Phytopathology 51:826-831.

95. Molina, J. J., and Harrison, M. D. 1977. The role of Erwinia carotovora in the epidemiology of potato blackleg. I. Relationship of E. carotovora var. carotovora and E. carotovora var. atroseptica to potato blackleg in Colorado. Am. Potato J. 54:587-591.

96. Molina, J. J., and Harrison, M. D. 1980. The role of Erwinia carotovora in the epidemiology of potato blackleg. II. The effect of soil temperature on disease severity. Am. Potato J. 57:351-363.

97. Munnecke, D. E. 1960. Bacterial stem rot of Dieffenbachia. Phytopathology 50:696-700.

98. Nassar, A., Darrasse, A., Lemattre, M., Kotoujansky, A., Dervin, C., Vedel, R., and Bertheau, Y. 1996. Characterization of Erwinia chrysanthemi by pectinolytic isozyme polymorphism and restriction fragment length polymorphism analysis of PCR-amplified fragments of pel genes. Appl. Environ. Microbiol. 62:2228-2235.

99. Ngwira, N., and Samson, R. 1990. Erwinia chrysanthemi: Description of two new biovars (bv. 8 and bv. 9) isolated from kalanchoe and maize host plants. Agronomie 10:341-345.

100. Nørskov-Lauritsen, N., Bruun, B., and Kilian, M. 2005. Multilocus sequence phylogenetic study of the genus Haemophilus with description of Haemophilus pittmaniae sp. nov. Int. J. Syst. Evol. Microbiol. 55:449-456.

101. Page, R. D. M., and Holmes, E. C. 1998. Molecular Evolution, a Phylogenetic Approach. Blackwell Scientific, Oxford, UK.

102. Palacio-Bielsa, A., Cambra, M. A., and López, M. M. 2006. Characterization of potato isolates of Dickeya chrysanthemi in Spain by a microtitre system for biovar determination. Ann. Appl. Biol. 148:157-164.

103. Panagopoulos, C. G., and Psallidas, P. G. 1970. A bacterial soft rot of cyclamen. Ann. Inst. Phytopathol. Benaki 9:83-93.

104. Pierce, L., and McCain, A. H. 1987. Alfalfa sprout rot caused by Erwinia chrysanthemi. Phytopathology 71:786-788.

105. Posada, D., and Buckley, T. R. 2004. Model selection and model averaging in phylogenetics: Advantages of akaike information criterion and Bayesian approaches over likelihood ratio tests. Syst. Biol. 53:793808.

106. Posada, D., and Crandall, K. A. 1998. MODELTEST: Testing the model of DNA substitution. Bioinformatics 14:817-818.

107. Rasolofo, R., and Dadant, R. 1962. Dépérissement du géranium rosat Pelargonium capitatum aux Comores. Agron. Trop. 12:1084-1088.

108. Romeiro, R. S., Sousa, R. M., Muchovej, J. J., and Kimura, O. 1988 Soft rot of Peruvian carrot due to Erwinia carotovora in Brazil. Plant Pathol. 37:300-302.

109. Saaltink, G. J., and Kamerman, W. 1971. Begonia bertinii, a new host of Erwinia chrysanthemi. Neth. J. Plant Pathol. 77:25-29.

110. Saaltink, G. J., and Maas Gesteranus, H. P. 1964. Bacterial wilt of dahlia. (Een bacterieverwelkingsziekte bij Dahlia). Meded. Landbouwhogesch. Lab. Bloembollenonderzoek. Lisbe 29:908-916.

111. Sabet, K. A. 1954. A new bacterial disease of maize in Egypt. Emp. J. Exp. Agric. 85:65-67.

112. Samson, R., Legendre, J. B., Christen, R., Fischer-Le Saux, M., Achouak, W., and Gardan, L. 2005. Transfer of Pectobacterium chrysanthemi (Burkholder et al. 1953) Brenner et al. 1973 and Brenneria paradisiaca to the genus Dickeya gen. nov. as Dickeya chrysanthemi comb. nov. and Dickeya paradisiaca comb. nov. and delineation of four novel species, Dickeya dadantii sp nov., Dickeya dianthicola sp. nov., Dickeya dieffenbachiae sp. nov. and Dickeya zeae sp. nov. Int. J. Syst. Evol. Microbiol. 55:1415-1427.

113. Schaad, N. W., and Brenner, D. 1977. A bacterial wilt and root rot of sweet potato caused by Erwinia chrysanthemi. Phytopathology 67:302308. 
114. Schuerger, A. C., and Batzer, J. C. 1993. Identification and host range of an Erwinia pathogen causing stem rots on hydroponically grown plants. Plant Dis. 77:472-477.

115. Segall, R. H. 1971. Selective medium for enumerating Erwinia species commonly found in vegetable packinghouse waters. Phytopathology 61:425-426.

116. Seo, S. T., Furuya, N., Lim, C.-K., Tsuchiya, K., and Takanami, Y. 2001. Variation of Erwinia carotovora subsp. carotovora isolated from Korea. J. Fac. Agric. Kyushu Univ. 45:431-436.

117. Shillingford, C. A. 1974. Bacterial rhizome rot of banana in Jamaica. Plant Dis. Rep. 58:214-218.

118. Shimodaira, H., and Hasegawa, M. 1999. Multiple comparisons of loglikelihoods with applications to phylogenetic inference. Mol. Biol. Evol. 16:1114-1116.

119. Shimodaira, H., and Hasegawa, M. 2001. CONSEL: For assessing the confidence of phylogenetic tree selection. Bioinformatics 17:1246-1247.

120. Smith, M. A. 1944. Bacterial soft rot of spinach. Phytopathology 34:747-752.

121. Sonoda, R. M., and Rhode, R. G. 1985. First report of Erwinia carotovora var. carotovora stem canker and wilt of zucchini squash. Plant Dis. 69:613.

122. Spurr, H. W., Echandi, E., Haning, B. C., and Todd, F. A. 1980. Bacterial barn rot of flue-cured tobacco in North Carolina. Plant Dis. 64:10201022.

123. Starr, M. P. 1947. The cause of bacterial root and stem disease of guayule. Phytopathology 37:291-300.

124. Staskawicz, B. J., Dahlbeck, D., and Keen, N. T. 1984. Cloned avirulence gene of Pseudomonas syringae pv. glycinea determines race specific incompatibility of Glycine $\max$ (L.). Proc. Natl. Acad. Sci. USA 81:6024-6028.

125. Stone, W. 1966. A highly virulent Erwinia isolate from Arizona vegetables. Plant Dis. Rep. 50:414-418.

126. Stover, R. H. 1959. Bacterial rhizome rot of bananas. Phytopathology 49:290-292.

127. Swofford, D. L. PAUP: Phylogenetic Analysis Using Parsimony (and Other Methods). 4. Sinaur Associates, Sunderland, MA.

128. Takahashi, K., and Sato, M. 1978. The shoot soft rot of mulberry caused by Erwinia carotovora var. carotovora (Jones) DYE. J. Seric. Sci. Jpn. 47:143-154.

129. Takimoto, S. 1931. A soft rot of sugarbeet and its causal organisms. Ann. Phytopathol. Soc. Jpn. 2:350-356.

130. Tamura, K., and Nei, M. 1993. Estimation of the number of nucleotide substitutions in the control region of mitochondrial DNA in humans and chimpanzees. Mol. Biol. Evol. 10:512-526.

131. Tanii, A., and Baba, T. 1971. Bacterial plant diseases in Hokkaido II. Bacterial stem rot of potato plant caused by Erwinia chrysanthemi Burkholder et al. (Pectobacterium carotovorum var. chrysanthemi). Bull. Hokkaido Prefect. Agric. Exp. Stn. 24:1-10.

132. Thompson, A. 1937. Pineapple fruit rots in Malaya. A preliminary report on fruit rots of the Singapore canning cultivar. Malay. Agric. J. 30:407420.

133. Thomson, S. V., Hills, F. J., Whitney, E. D., and Schroth, M. N. 1981. Sugar and root yield of sugar beets as affected by bacterial vascular necrosis and rot, nitrogen fertilization, and plant spacing. Phytopathology 71:605-608.

134. Thomson, S. V., and Schroth, M. N. 1972. Vascular necrosis and rot of sugarbeets. Calif. Plant Pathol. 12:1-2.

135. Tomlinson, D. L. 1988. A leaf and fruit disease of Pandanus conoideus caused by Erwinia carotovora subsp. carotovora in Papua New Guinea. J. Phytopathol. 121:19-25.

136. Tomlinson, D. L., and Cox, P. G. 1987. A new disease of cardamom (Elettaria cardamomum) caused by Erwinia chrysanthemi in Papua New Guinea. Plant Pathol. 36:79-83.

137. Towner, D. B., and Beraha, L. 1976. Core-rot: A bacterial disease of carrots. Plant Dis. Rep. 60:357-359.

138. Townsend, C. O. 1904. A soft-rot of the calla lily. Bull. U. S. Bur. Plant Ind. 60.

139. Tsuyama, H. 1962. Studies on the soft rot disease of Chinese cabbage caused by Erwinia aroideae (Towns.) Holland. Bull. Inst. Agric. Res. Tohoku Univ.:335-340.

140. Volcani, Z. 1954. Bacterial soft rot of avocado fruit. Nature 174:604605.

141. Volcani, Z. 1957. Soft rot on Japanese radish caused by a strain of Erwinia carotovora. J. Agric. Res. Stn. Rehovet Ktavim 7:141-142.

142. Volcani, Z. 1961. Soft rot of pepper fruits in storage caused by Erwinia carotovora var. aroideae. Israel J. Agric. Res 11:207-208.

143. Waldee, E. L. 1945. Comparative studies of some peritrichous phytopathogenic bacteria. Iowa State Coll. J. Sci. 19:435-484.

144. Wehlburg, C., and Meyer, R. W. 1966. Bacterial soft rot of iceberg (Great Lakes) lettuce in the Florida Everglades. Plant Dis. Rep. 50:938941.

145. Wimalajeewa, D. L. S. 1976. Studies on bacterial soft rot of celery in Vicotoria. Aust. J. Exp. Agric. Anim. Husb. 16:915-920.

146. Yap, M.-N., Barak, J. D., and Charkowski, A. O. 2004. Genomic diversity of Erwinia carotovora subsp. carotovora and its correlation with virulence. Appl. Environ. Microbiol. 70:3013-3023. 